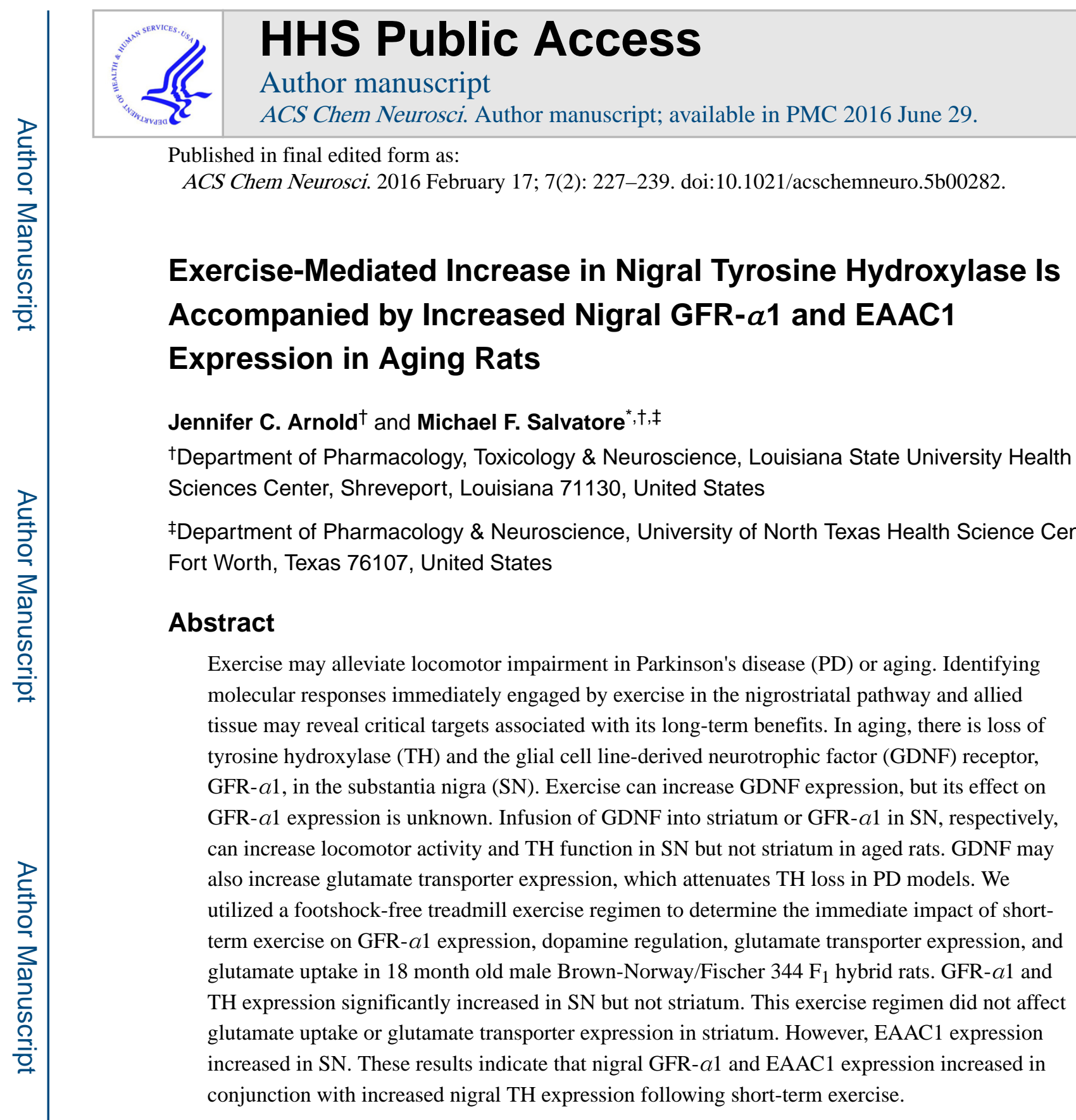

Published in final edited form as:

ACS Chem Neurosci. 2016 February 17; 7(2): 227-239. doi:10.1021/acschemneuro.5b00282.

\title{
Exercise-Mediated Increase in Nigral Tyrosine Hydroxylase Is Accompanied by Increased Nigral GFR-a1 and EAAC1 Expression in Aging Rats
}

\author{
Jennifer C. Arnold ${ }^{\dagger}$ and Michael F. Salvatore ${ }^{\star}, \dagger, \ddagger$ \\ Department of Pharmacology, Toxicology \& Neuroscience, Louisiana State University Health \\ ¥Department of Pharmacology \& Neuroscience, University of North Texas Health Science Center, \\ Fort Worth, Texas 76107, United States
}

\section{Abstract}

\begin{abstract}
Exercise may alleviate locomotor inpairment in Parkinson's disease (PD) or aging. Identifying molecular responses immediately engaged by exercise in the nigrostriatal pathway and allied tissue may reveal critical targets associated with its long-term benefits. In aging, there is loss of tyrosine hydroxylase (TH) and the glial cell line-derived neurotrophic factor (GDNF) receptor, GFR- $a 1$, in the substantia nigra (SN). Exercise can increase GDNF expression, but its effect on GFR- $a 1$ expression is unknown. Infusion of GDNF into striatum or GFR- $a 1$ in SN, respectively, can increase locomotor activity and TH function in SN but not striatum in aged rats. GDNF may also increase glutamate transporter expression, which attenuates TH loss in PD models. We utilized a footshock-free treadmill exercise regimen to determine the immediate impact of shortterm exercise on GFR- $\alpha 1$ expression, dopamine regulation, glutamate transporter expression, and glutamate uptake in 18 month old male Brown-Norway/Fischer $344 \mathrm{~F}_{1}$ hybrid rats. GFR- $\alpha 1$ and TH expression significantly increased in SN but not striatum. This exercise regimen did not affect glutamate uptake or glutamate transporter expression in striatum. However, EAAC1 expression conjunction with increased nigral TH expression following short-term exercise.
\end{abstract}

\footnotetext{
*Corresponding Author michael.salvatore@unthsc.edu. Author Contributions

Conceived and designed the experiments: M.F.S. and J.C.A. Conducted experiments: J.C.A. Performed data analysis: J.C.A. and M.F.S., Contributed reagents/materials/analysis tools: M.F.S. Wrote manuscript: J.C.A. and M.F.S.

The authors declare no competing financial interest.

Supporting Information

The Supporting Information is available free of charge on the ACS Publications website at DOI: 10.1021/acschemneuro.5b00282. Effects of exercise on DAT expression in the striatum, VTA, and NAc (Figure S1); TH phosphorylation stoichiometry in the striatum following exercise (Table S1) (PDF)
} 


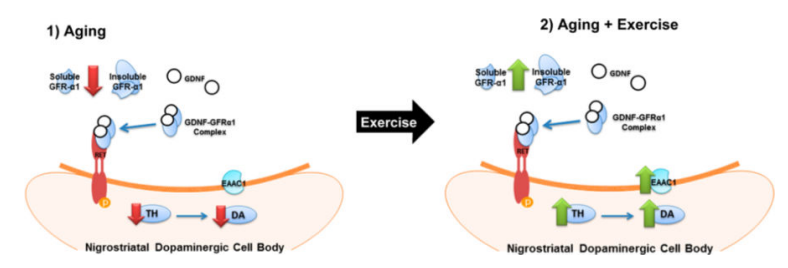

\section{Keywords}

Aging; exercise; tyrosine hydroxylase; GFR- $\alpha$ 1; EAAC1; substantia nigra

Physical exercise exhibits widespread health benefits and may reduce the risk for neurodegenerative diseases, such as Parkinson's disease (PD).' Exercise may also improve locomotor impairments, such as bradykinesia, observed in PD' and aging. In the elderly, 12 weeks of exercise improved timed up and go performance in 67-76 year olds. However, the behavioral and molecular effects of exercise on mechanisms associated with aging-related locomotor impairments have not been examined in aging models. These studies are essential since the number of retirees will double in 15 years. Thus, identifying molecular responses immediately engaged by exercise in the entire nigrostriatal pathway could reveal critical molecular targets associated with the long-term effects of exercise, particularly in relation to locomotor function.

Exercise may preserve functional nigrostriatal dopamine (DA) neurons and attenuate nigrostriatal DA loss, in conjunction with improved motor function in PD models.- Since locomotor impairments occur in PD and aging, the neurobiological basis may originate from a common molecular mechanism, and exercise may attenuate molecular deficits associated with locomotor impairment. In PD models and patients, the onset of bradykinesia is associated with 70-80\% loss of striatal DA and tyrosine hydroxylase (TH), ${ }^{-}$but this threshold of striatal DA loss has not been reported in aging studies, wherein striatal DA loss is highly variable $(0-50 \%))^{-}$No significant loss of striatal TH has been reported in aging humans $^{-}$or animal models." However, loss of DA ( 40-60\%) and TH $(\sim 30-50 \%)$ in the substantia nigra (SN) may be similar at the onset of locomotor impairment in PD and aging,,-, although this possibility has not been rigorously examined. This suggests that loss of nigral TH or DA may contribute to locomotor impairment in PD or aging. Notably, several studies have reported exercise-mediated improvements of locomotor function with little impact on striatal DA or TH.- This further highlights the importance of examining the impact of exercise on DA regulation in the entire nigrostriatal pathway.

Exercise increases glial cell line-derived neurotrophic factor (GDNF) expression in CNS and PNS tissues. Increased GDNF expression occurs in response to short-' or long-term exercise regimens. Exercise may potentially reverse nigrostriatal TH loss in association with increased nigrostriatal GDNF expression, as observed in PD models.' Although the effects of exercise on nigrostriatal GDNF expression in aged animals have not been reported, GDNF expression increased in other CNS tissues in aged rats following short-term exercise. Collectively, these results suggest that exercise may increase nigrostriatal GDNF expression in aged rats, which may offset aging-related decreases in TH expression. Notably, GDNF 
effects on the nigrostriatal pathway may be dichotomous, or compartment specific. For example, administration of GDNF intranigrally, intracerebrally, or in the right lateral ventral adjacent to the striatum increased DA in SN but not striatum, whereas striatal administration of GDNF increased TH phosphorylation to a greater extent in SN. Similarly, we previously reported that the main cognate receptor for GDNF, GFR- $a 1$, is significantly decreased in the $\mathrm{SN}$ in conjunction with decreased TH protein expression, DA tissue content, and locomotor activity in aged versus middle-aged rats.' Delivery of GFR- $a 1$ into the SN increases nigral but not striatal TH protein expression and DA tissue content with increased locomotor activity in aged rats. Therefore, exercise could be a strategy to mitigate age-related loss of nigral TH protein and DA tissue content by enhancing GDNF signaling through GFR- $a 1$. Another possible, but far less examined, mechanism of exercise-mediated protection is a reduction of the potential for glutamate excitotoxicity. For example, GDNF mice exhibit increased extracellular glutamate and glutamate release in the $\mathrm{SN}$ and a reduction in nigral glutamate uptake in combination with decreased nigral glutamate transporter-1 (GLT-1) expression. GDNF may also increase expression of glutamate aspartate transporter (GLAST) in retinal cells.

Here, we determined the immediate effects of short-term exercise on nigrostriatal DA regulation, glutamate transporter expression, and striatal glutamate uptake in advanced middle age (18 month old) male Brown-Norway/Fischer $344 \mathrm{~F}_{1}$ hybrid rats. We also measured GFR- $a 1$ expression in the nigrostriatal pathway and allied tissue of these rats following exercise. The treadmill exercise regimen utilized herein has several clinically translatable components that may be particularly advantageous for aging studies, including a footshock-free paradigm with nearly $100 \%$ compliance to treadmill exercise, a moderate speed and duration of exercise, and the inclusion of a rest period between each round of exercise.

\section{RESULTS}

The treadmill exercise regimen employed in this study is described in further detail in the methods and in Figure 1. Following a treadmill acclimation period, in which exercise and non-exercise rats were trained to exercise on the treadmill, the exercise group underwent two rounds of treadmill exercise. Each round of exercise lasted for 12 consecutive days, and a 14 day rest period separated the two rounds of exercise. The duration of all treadmill exercise sessions was $35 \mathrm{~min}$ and included a $5 \mathrm{~min}$ warm-up period where rats exercised at slower speeds $(8 \mathrm{~m} / \mathrm{min})$ than the exercise speeds $(9-11 \mathrm{~m} / \mathrm{min})$ maintained for the reminder of the session (30 $\mathrm{min})$. Non-exercise rats did not exercise during the treadmill exercise period. However, to control for the treadmill environment, the non-exercise rats sat on the stationary treadmill for the same duration (35 min) that their exercise cohorts trained during each session. All rats were sacrificed within an hour following the last exercise session, and brain tissue was dissected from the $\mathrm{SN}$, dorsal striatum (i.e., striatum), ventral tegmental area (VTA), and nucleus accumbens (NAc) to assess the immediate effects of exercise on DA regulation in the nigrostriatal and messoaccumbens DA pathways, nigrostriatal glutamate transporter expression, and striatal glutamate uptake. 


\section{Exercise and GFR-a1 Expression}

Two forms of GFR- $a 1$ exist: a glycosyl-phosphatidylinositol (GPI)-linked (insoluble) receptor $(\sim 52 \mathrm{kDa})$ located on outer cellular membranes and a cleaved (soluble) receptor $(\sim 48 \mathrm{kDa})$ that functions independently of insoluble GFR- $a 1$ and is located in the extracellular space.' The expression of total GFR- $\alpha 1$ (insoluble and soluble forms) significantly increased in the SN (Figure 2A,B) but not striatum (Figure 2E) after two rounds of exercise. The insoluble form of GFR- $a 1$ increased ( 28\%) in SN (Figure 2A,C) but not striatum (Figure $2 \mathrm{~F}$ ) following exercise. Soluble GFR- $\alpha 1$ expression showed a trend toward a significant increase in $\mathrm{SN}(p=0.10$, Figure $2 \mathrm{~A}, \mathrm{D})$ but not striatum (Figure $2 \mathrm{G}$ ) after exercise.

GFR- $a 1$ expression in the mesoaccumbens DA pathway was not affected by the exercise regimen (Figure 3). Thus, given the extent to which these rats were exercised in this study, this regimen affected GFR- $\alpha 1$ expression strictly in the SN.

\section{Exercise and TH Protein Expression}

Aging-related TH loss in the SN (but not striatum) has been reported previously.-", Nigral TH protein expression was significantly increased $(\sim 42 \%)$ in exercise rats after exercise compared to that in non-exercise rats (Figure 4A,E). This effect was limited to the SN, as striatal TH protein expression was not significantly different between the groups (Figure 4B). TH protein expression was also not affected by the regimen in the VTA (Figure 4C) or NAc (Figure 4D).

\section{Exercise and TH Phosphorylation}

Ser19 and Ser31 TH phosphorylation in striatum was not affected by the exercise regimen (Supporting Information, Table S1). Given the limited tissue for use in striatal glutamate uptake studies, the priority was to examine Ser31 over Ser40 given recent data supporting a role for Ser31 TH phosphorylation in regulating DA tissue content in nigrostriatal tissues."

\section{Exercise and DA Tissue Content}

Given the effect of increased nigral GFR- $\alpha 1$ and TH protein expression after two rounds of exercise, we hypothesized that exercise would also increase DA tissue content in the SN. Nigral DA tissue content was significantly increased ( $23 \%)$ in exercise rats compared to that in non-exercise rats (Figure 5A). Conversely, DA tissue content was not significantly different in the VTA (Figure 5B) or NAc (Figure 5C) after exercise.

The method used to assay glutamate uptake in the striatum precluded us from measuring striatal DA tissue content. However, we have previously reported that DA tissue content and TH protein covary in all DA tissues analyzed herein. Therefore, we would not expect any difference in striatal DA tissue content given no difference in striatal TH protein content or Ser31 TH phosphorylation.

\section{Relationship of GFR-a1 Expression to Total TH Protein and DA Tissue Content}

With this regimen, we have shown that exercise increased nigral GFR- $\alpha 1$ expression, TH protein expression, and DA tissue content in aging rats (Figures 2, 4, and 5). To explore the 
relationship of GFR- $\alpha 1$ expression to TH protein expression and DA tissue content, a correlational analysis was performed for all four brain regions. In the $\mathrm{SN}$, insoluble and soluble GFR- $\alpha 1$ levels positively correlated to nigral TH and DA (Figure 6). Insoluble GFR$a 1$ was significantly correlated to TH (Pearson $r=0.54, p<0.05$, data not shown) and DA (Pearson $r=0.57, p<0.05$, data not shown) in the VTA, whereas soluble GFR- $\alpha 1$ was positively correlated to TH in striatum (Pearson $r=0.54, p<0.05$, data not shown).

Conversely, insoluble and soluble GFR- $a 1$ were not significantly correlated to either TH or DA in the NAc (data not shown).

\section{Exercise and Other Markers of DA Neurotransmission}

We examined other components of DA neurotransmission that may be affected by exercise, including the dopamine transporter (DAT) and the DA- $\mathrm{D}_{1}$ receptor. The expression of DAT may decrease following GDNF, and modulation of DA- $\mathrm{D}_{1}$ receptor function in $\mathrm{SN}$ affects basal ganglia function' and open-field locomotion. DA- $\mathrm{D}_{1}$ receptor expression was not significantly different in the SN (Figure 7A), striatum (Figure 7B), or NAc (Figure 7D). However, we observed an increase $(\sim 18 \%)$ in DA- $\mathrm{D}_{1}$ receptor expression in the VTA in exercise rats compared to that in non-exercise rats (Figure 7C,E). No significant differences were observed in DAT expression in the striatum, VTA, or NAc (Supporting Information, Figure S1) after exercise. Limited tissue availability in SN after assessment of other dependent measures prevented analysis of DAT therein.

\section{Exercise and Glutamate Uptake and Glutamate Transporter Expression}

In the $\mathrm{SN}$, there was a significant increase $(22 \%)$ in EAAC1 expression (Figure $8 \mathrm{~A}, \mathrm{G})$ in exercise rats compared to that in non-exercise rats. There was no significant difference in nigral GLT-1 expression (Figure 8B), but a trend toward a significant increase in nigral GLAST expression ( $p=0.050$; Figure $8 \mathrm{C}$ ) was observed. In striatum, we did not observe any significant differences in glutamate uptake (Figure 8D), GLT-1 expression (Figure 8E), or GLAST expression (Figure 8F) after exercise. We were unable to measure striatal EAAC1 expression given the quantity of tissue needed to assay glutamate uptake. The significance of increased nigral EAAC1 expression may be related to its ability to transport cysteine, the rate-limiting substrate in glutathione synthesis, into neurons.-

Table 1 summarizes all of the neurochemical parameters measured in the SN, striatum, VTA, and NAc following two rounds of exercise.

\section{DISCUSSION}

The molecular basis of how exercise regimens may attenuate the progression of neurodegenerative disease processes in models of PD and Alzheimer's disease has been studied using both voluntary and forced exercise regimens. Our study represents another step forward toward understanding how forced (treadmill) exercise may attenuate adverse effects of aging that occur in the nigrostriatal DA pathway. Here, our results show that late-middleaged (18 months) rats are compliant in a footshock-free regimen of treadmill exercise. This increase in $\mathrm{TH}$ protein is speculated to attenuate loss of nigral TH protein that occurs during aging in rodents, including the strain used herein,' non-human primates, and humans alike. 
The relatively short-term application of this exercise regimen appears to selectively increase GFR- $\alpha 1$ expression, TH expression, and DA tissue content, only in the SN, in aging BrownNorway/Fischer $344 \mathrm{~F}_{1}$ hybrid rats. This effect appears to be limited to the somatodendritic region of the nigrostriatal pathway, as GFR- $\alpha 1$ expression and TH expression and phosphorylation were not affected in the striatum. In terms of the potential exercise impact on aging-related processes, this outcome may be related to previous observations that aging itself also does not affect $\mathrm{TH}$ protein expression in striatum of aging humans, non-human primates, and rodents. ${ }^{-,}$However, we did not measure other components of DA neurotransmission in striatum. For example, DA release, which is increased by GDNF, was not measured in this study. Therefore, we have only begun to thoroughly evaluate the impact of this regimen on DA neurotransmission. Still, there is evidence that the effects were largely limited to the SN, as these effects were also not observed in the VTA, the dopaminergic region of the mesoaccumbens pathway. However, an increase in $\mathrm{D}_{1}$ receptor expression was limited to the VTA and not observed in the SN.

The idea that long-term exercise could potentially reduce risk or severity of aging-related locomotor impairments, like bradykinesia, by affecting nigral TH expression was hypothesized based upon observations that most exercise regimens performed in PD models and patients show some level of improvement in locomotor function,,-,- even in the absence of effects on striatal DA measures in PD models. ${ }^{-}$What seems to be clear, however, is that exercise increases expression of neurotrophic factors such as GDNF in CNS and PNS tissues. Furthermore, striatal GDNF administration increases GFR- $\alpha 1$ expression in the SN, but it decreases GFR- $a 1$ and TH expression in striatum. GDNF administration also selectively increased TH protein expression and DA tissue content in SN but not striatum in combination with increased locomotor activity. ${ }^{-}$Finally, our recent work indicates that increasing GFR- $a 1$ expression in the $\mathrm{SN}$ alone increases nigral $\mathrm{TH}$ protein expression and DA tissue content in conjunction with increased locomotor activity in aged rats, and these effects essentially reverse aging-related loss of GFR- $\alpha 1$, TH protein, and DA in SN alone. Thus, strategies, such as exercise, that enhance GDNF signaling through GFR- $a 1$ could preserve functional nigrostriatal DA neurons by increasing nigral TH protein.

\section{Significance of Increased Nigral GFR- $a 1$ Expression Following Exercise}

Total GFR- $a 1$ expression and insoluble GFR- $\alpha 1$ expression were significantly increased, only in the SN, following exercise (Figure $2 \mathrm{~A}-\mathrm{C}$ ). While not significant, there was a trend toward a significant increase in nigral soluble GFR- $a 1$ expression $(p=0.10$; Figure 2A,D). To our knowledge, this is the first study to demonstrate increased GFR- $\alpha 1$ expression in any brain region in response to exercise. There was a notable decrease in the expression of insoluble GFR- $a 1$ in striatum, though it was not statistically significant $(p=0.14)$. The possibility remains that there could be differential transport of GFR- $\alpha 1$ between the SN and striatum, given the differences in expression after exercise. In fact, one study reported significant decreases in GFR- $\alpha 1$ in striatum but increases in SN following exogenous delivery of GDNF into striatum.

In light of recent work, the exercise effects specific to the SN suggest that long-term exercise could offset aging-related loss of nigral DA function. This specific neuroanatomical effect of 
exercise in the SN may target an inherent aging-related deficit in GFR- $\alpha 1$ at 18 months of age, which we have reported to occur sometime between 12 and 30 months only in the SN in this strain of rats. Expression of GFR- $\alpha 1$ may be critical for sustaining normal neuronal functions, as influenced by GDNF. In fact, decreased expression was recently shown in Alzheimer's disease, with reduced levels of this specific GFR- $a 1$ receptor subtype observed in cultured cortical neurons obtained post-mortem from these patients. Furthermore, a specific decrease in an isoform of GFR- $\alpha 1$ has been shown in the basolateral amygdala of depressed patients. Exercise has been shown to be effective in reducing cognitive impairment and depressive-like behavior. The involvement of increased GFR- $\alpha 1$ expression following exercise to reduce these adverse behavioral outcomes is possible, though yet unknown.

Although it is well-established that exercise increases neurotrophic factors such as GDNF in CNS tissue, we could not draw a definitive conclusion as to whether our regimen affected GDNF expression due to limited tissue available, methodological priorities in tissue processing, and prioritizing to examining expression levels of its receptor, as one study previously reported that exogenous GDNF delivered into striatum could increase GFR- $a 1$ expression in SN.

\section{Significance of Increased Nigral TH and DA in Response to Exercise}

We observed increased nigral TH protein (Figure 4A,E) and DA tissue content (Figure 5A) following the exercise regimen. Others have also reported increased nigral TH expression or TH-positive cells following running wheel or treadmill exercise in PD models, and involvement of increased growth factor expression and mitochondrial function. The behavioral significance of increased TH expression may be dependent upon the initial severity of TH loss prior to exercise and the length of exercise time, the neurobiological background of TH expression, and the longevity of increased expression following cessation of exercise. In our work, assessment of locomotor function requires 5 daily $1 \mathrm{~h}$ assessments in an open-field locomotor test to reduce the influence of daily variation in locomotor activity. We have also reported that TH protein loss occurs strictly in the SN between 12 and 30 months of age and between 18 and 24 months of age in the same rat strain used herein. Therefore, the $\sim 40 \%$ increase in nigral TH expression observed following this regimen could conceivably offset the $\sim 30-40 \%$ reduction in nigral $\mathrm{TH}$ expression, previously observed in this strain, with continuation of this regimen out to 24 months of age.

In the same vein, as previously mentioned, TH expression in striatum has been shown in many studies to be relatively unaffected by aging in this strain, in other animals models, and in humans. While the technical limitation for our priority to measure striatal glutamate uptake in the precluded us from measuring DA tissue content in the striatum, we observed no effect on striatal TH protein expression (Figure 4B) therein despite increased TH expression in the SN (Figure 4A) and no effect on striatal Ser31 TH phosphorylation (Supporting Information, Table S1). This dichotomy in TH regulation between the striatum and SN has been reported by our lab" and also observed in human aging studies.' Thus, given the increase in nigral TH expression, this dichotomy may be related to the intensity and frequency of exercise in the paradigms, or differences in expression of GFR- $\alpha 1$ isoforms 
between these two DA pathways. A certain threshold of exercise intensity or duration may be required for CNS impact" and, in this case, may be compartment-specific.

\section{Significance of Increased Nigral EAAC1 Expression in Response to Exercise}

The increase in nigral EAAC1 expression following exercise may signify a potential neuroprotective response. EAAC1 is a $\mathrm{Na}^{+}$-dependent, high-affinity glutamate transporter that is expressed on CNS neurons, with particularly dense expression on dopaminergic neurons in the SN. Although EAAC1 may play a comparatively minor role in glutamate uptake, EAAC1 also transports cysteine' and is a major mechanism for neuronal uptake of cysteine. In the $E A A C 1^{-1-}$ mouse, deficient neuronal cysteine uptake results in chronic neuronal oxidative stress and early onset brain atrophy, in conjunction with loss of dopaminergic neurons and increased markers of oxidative stress in the SN. The characteristic loss of nigral DA neurons that occurs in both PD and aging may be partially attributed to increased oxidative stress that occurs in PD and aging and age-dependent vulnerability to oxidant injury, TH loss, and impaired motor function, notably, without any loss of striatal DA. To our knowledge, this is the first observation that exercise can affect EAAC1 expression in the CNS.

We also investigated whether striatal glutamate uptake would be enhanced by the exercise regimen. Striatal glutamate uptake decreases at 18 months of age in rats, and increased glutamate uptake is associated with attenuated TH protein loss in PD models. Furthermore, given well-documented effects of exercise on GDNF expression, recent work indicates that GDNF affects glutamate uptake in CNS tissues.' Glutamate uptake is mediated primarily by GLT-1 and GLAST and is important for terminating glutamatergic neurotransmission and reducing the potential for excitotoxicity. Glutamate-induced excitotoxicity has been implicated in neurodegenerative diseases, including PD, and evidence suggests that glutamate-induced excitotoxicity contributes to loss of nigrostriatal DA neurons in PD. Although we did not observe significant differences in striatal glutamate uptake or expression of GLT-1 and GLAST in striatum with this regimen, there may be a functional outcome associated with nigral GLAST expression, which increased in the exercise group but was just beyond the level of significance ( $p=0.050$, Figure $8 \mathrm{C}$ ).

\section{SUMMARY}

Two rounds of our exercise regimen increased nigral TH protein levels, GFR- $\alpha 1$ expression, EAAC1 expression, and DA tissue content in the SN. Our findings certainly do not present the totality of mechanisms by which exercise may affect the nigrostriatal pathway. For example, exercise increases brain-derived neurotrophic factor (BDNF) expression' and TrkB receptor expression, a result akin to our finding of increased GFR- $\alpha 1$ expression, and may be critical in exercise-mediated protection against MPTP-induced neurotoxicity. We have previously reported that age-related decreases in nigral GFR- $a 1$ expression, TH protein expression, and DA tissue content coincide with decreased locomotor activity in aged rats." Therefore, longitudinal application of this regimen may address if these increases in $\mathrm{TH}$ protein levels, GFR- $a 1$ expression, EAAC1 expression still occur with possible attenuation of aging-related locomotor deficits. Accordingly, we are continuing this work to determine 
the extent to which this regimen may improve aging-related bradykinesia. We are also examining if long-term application of this regimen will still produce increased GFR- $a 1$, TH, and EAAC1 expression in the $\mathrm{SN}$ as the rats continue aging. Finally, we note that the reported effects of this footshock-free treadmill exercise regimen occurred by incorporating a significant rest period between each round of exercise, training the non-exercise control group to exercise during the treadmill acclimation period, and controlling for possible stress in the treadmill environment by resting the non-exercise subjects on the stationary treadmill for the same duration that the exercised cohorts experienced each session during the regimen. Thus, this study also represents a further extension of exercise research by controlling for stressors and environmental conditions that can influence catecholamine function. It also gives due attention to focus on functional measures of DA in the SN involving exercise-related locomotor benefits.

\section{METHODS}

\section{Animals}

Eighteen month old male Brown-Norway/Fischer $344 \mathrm{~F}_{1}$ hybrid rats $(n=16)$ were obtained from the National Institute on Aging and singly housed under controlled colony conditions with a $12 \mathrm{~h}$ reverse light-dark cycle (lights on at $1800 \mathrm{~h}$ ). Rats had access to food and water ad libitum. Behavioral experiments were conducted during the rats' active (dark) portion of the light-dark cycle and were completed before 16:30. All procedures were conducted in accordance with the Federal and Institutional Animal Care and Use Committee guidelines at LSU Health Sciences Center.

\section{Treadmill Exercise Regimen}

The treadmill exercise regimen employed in this study was conducted as previously described. This regimen is composed of three separate phases: the pre-exercise, treadmill acclimation, and treadmill exercise phases. A brief overview of this regimen is described below and in Figure 1.

\section{Pre-exercise Procedures}

Body Weight-To assess the physiological effects of exercise on test subjects, body weights were recorded for all rats before (first session) and after (last session) each phase of the regimen. We previously reported that this regimen produces a physiological effect of exercise on body weight, as exercise rats lost significantly more weight compared to that for non-exercise rats across the regimen, resulting in $\sim 4 \%$ decrease in body weight in exercise rats.

Baseline Locomotor Activity-Baseline locomotor activity was determined for 60 min per day for 5 consecutive days in open-field locomotor activity chambers (Opto Varimex 4 Animal Activity Monitoring System, Columbus Instruments, Columbus, OH, USA), as previously described. Locomotor activity was assessed prior to initiation of exercise to ensure that an equal range of locomotor capabilities was represented in both groups. However, locomotor activity was not assessed following exercise since the goal of this study was to determine the immediate impact of exercise on nigrostriatal DA regulation, glutamate 
transporter expression, and striatal glutamate uptake, and our assessment of locomotor activity requires 5 daily $1 \mathrm{~h}$ sessions to determine a locomotor activity profile.'

\section{Treadmill Acclimation Phase}

Acclimation Phase 1-All treadmill acclimation and exercise sessions were performed on a motorized rodent treadmill (Exer-4, Columbus Instruments, Columbus, OH, USA). Exercise was conducted on a treadmill because the frequency, intensity, and duration of exercise are controlled by the experimenter. To acclimate rats to the treadmill environment, exercise and non-exercise rats were first placed on the stationary treadmill for 3 consecutive days. Time spent on the stationary treadmill increased each day as follows: 5 min (day 1), 7 min (day 2), and 10 min (day 3).

Acclimation Phase 2-To ensure that all rats were capable of exercising, all subjects, including the non-exercise group, were trained to exercise on the treadmill during a 7 day acclimation period. Rats were trained to walk on the treadmill at a slow walking speed $(5 \mathrm{~m} /$ $\min$ ), and the speed and duration of sessions were increased with each session such that rats were trained at low speeds for the first three sessions $(5-7 \mathrm{~m} / \mathrm{min}$ for 5-7 $\mathrm{min})$ and at more moderate speeds for the last four sessions (8-9 $\mathrm{m} / \mathrm{min} ; 8-10 \mathrm{~min})$. With these acclimation procedures, we previously reported $\sim 100 \%$ compliance to exercise without the use of footshock at any time.

\section{Treadmill Exercise Phase}

Treadmill exercise was conducted in rounds, where one round of exercise continued for 12 days. Exercise rats underwent two rounds (24 total days) of exercise, and a 14 day rest period separated the two rounds of exercise. The duration of all training sessions was $35 \mathrm{~min}$ and included a 5 min warm-up period where rats exercised at lower speeds $(8 \mathrm{~m} / \mathrm{min})$ than the training speeds $(9-11 \mathrm{~m} / \mathrm{min}$ ) maintained for the reminder of the session $(30 \mathrm{~min})$. Exercise and non-exercise sessions were conducted separately, as non-exercise rats sat on the stationary treadmill for the same duration $(35 \mathrm{~min})$ that their exercise cohorts trained during each session.

\section{Tissue Collection and Analysis}

Rats were sacrificed by decapitation immediately following the last session of the second round of exercise to assess the immediate impact of exercise on DA tissue content, TH protein expression, GFR- $\alpha 1$ expression, DA transporter (DAT) expression, DA D 1 -receptor expression, glutamate uptake, and glutamate transporter (GLT-1, GLAST, and EAAC1) expression. Brain tissue was dissected from the SN, striatum, VTA, and NAc, as previously described. We did not perform any neurochemical analyses for one rat in the exercise group due to the discovery of a brain tumor during collection of brain tissue. For statistical analysis, the average value of the exercise group for each dependent measure was used in place of the result that would have otherwise been reported for this rat for each dependent measure. 


\section{Preparation of Synaptosomes for Glutamate Uptake}

Crude synaptosomes were prepared from striatal tissue as previously described.' Briefly, striatal tissue was homogenized in $0.32 \mathrm{M}$ sucrose solution using a Teflon/glass homogenizing wand followed by centrifugation at $1000 \mathrm{~g}$ for $10 \mathrm{~min}$. The resulting pellet (P1 fraction) was sonicated in sodium dodecyl sulfate (SDS) and boiled for 5 min. Protein concentration was determined using a bicinchoninic acid (BCA) assay, and the aliquot was stored at $-80{ }^{\circ} \mathrm{C}$ until total $\mathrm{TH}$ and soluble GFR- $\alpha 1$ expression were analyzed (this fraction can be utilized to determine expression of cytosolic proteins such as TH; see ref 62). The remaining supernatant was centrifuged at $17500 \mathrm{~g}$ for 30 min to yield the P2 fraction, which was used to determine striatal glutamate uptake on the day of preparation, with an aliquot prepared to determine GLT-1, GLAST, insoluble GFR- $\alpha 1$, DAT, and DA-D 1 receptor expression by western blot. The supernatant was extracted, and the pellet was resuspended in Krebs buffer.

\section{Glutamate Uptake Protocol}

The synaptosomal P2 fraction described above contains glial components, and $~ 70 \%$ of glial fibrillary acid protein levels are recovered in purified glial plasmalemmal vesicles, making them suitable for analysis of glutamate uptake.' A total of $30 \mu \mathrm{g}$ of synpatosome protein was used in a $200 \mu \mathrm{L}$ final volume for glutamate uptake. Prepared synaptosomes were subsequently placed into a water bath at $35^{\circ} \mathrm{C}$ for $5 \mathrm{~min}$. After $5 \mathrm{~min}, 100 \mu \mathrm{L}$ of 10 $\mu \mathrm{M}{ }^{14} \mathrm{C}(\mathrm{U})$-L-glutamic acid (PerkinElmer, specific activity $260 \mathrm{mCi} / \mathrm{mmol}$, cat. no. NEC290E050UC) was added to the synaptosomal preparations (yielding a $5 \mu \mathrm{M}$ final glutamate concentration) and allowed to incubate for reuptake for $90 \mathrm{~s}$. To terminate the reaction, $1 \mathrm{~mL}$ of ice-cold Krebs buffer was added to each tube, and the tubes were immersed into an ice bath. The $90 \mathrm{~s}$ reuptake time was chosen because it was determined to be as close as technically and practically possible to the $10 \mathrm{~s}$ reuptake of glutamate in vivo.' To remove excess labeled glutamate, synaptosomes were washed seven times with equalosmolarity phosphate-buffered saline through a Brandel M24-TI cell harvester with Brandel $\mathrm{GF} / \mathrm{C}$ filter paper pretreated with a $2 \%$ polyethylenimine solution to reduce nonspecific binding of the label. The filter paper containing the rinsed synaptosomes was transferred to vials that contained scintillation cocktail and counted with a Beckman Coulter scintillation counter.

\section{Quantifying Striatal $\left[{ }^{14} \mathrm{C}\right] \mathrm{Glutamate}$ Uptake in Synaptosomes}

Striatal glutamate uptake was determined by first taking the percent of glutamate (as the label) recovered in synaptosomes against total glutamate (as the label) uptake in the experiment. The percent of glutamate uptake averaged $4.65 \pm 0.26 \%$ (mean \pm SEM, $n=12$ ) using $5 \mu \mathrm{M}$ glutamate (final concentration). On the basis of the percentage of label recovery in synaptosomes, total picomoles of glutamate was determined and subsequently normalized to milligrams of protein per minute based on the allotted $90 \mathrm{~s}$ uptake time. Determination of striatal $\left[{ }^{14} \mathrm{C}\right]$ glutamate uptake in crude synaptosomes was conducted in triplicate for one exercise and one non-exercise rat simultaneously. 


\section{HPLC: DA Tissue Content}

Analysis of DA tissue content was determined in the SN, VTA, and NAc of exercise and non-exercise rats following the regimen. We did not measure striatal DA tissue content because the harvested tissue was apportioned for striatal glutamate uptake. Tissue from each brain region was stored at $-80{ }^{\circ} \mathrm{C}$ until sonication in $500 \mu \mathrm{L}$ of ice-cold $0.1 \mathrm{M} \mathrm{HClO}_{4}$-EDTA buffer. Aliquots from the protein-precipitated supernatants were analyzed for content of DA by HPLC as previously described. Treatment with the acid buffer for HPLC analyses results in precipitation of protein content in the sample.

\section{Tissue Preparation and Western Immunoblotting}

The previously prepared striatal synaptosome $\mathrm{P} 1$ and $\mathrm{P} 2$ fractions and the protein pellets for SN, VTA, and NAc were sonicated in a $1 \%$ SDS solution with $5 \mathrm{mM}$ Tris buffer $(\mathrm{pH} 8.3$ ) and $1 \mathrm{mM}$ EDTA using a Branson Sonifier 150 and boiled for 5 min. Protein concentration was assayed using the BCA colorimetric assay, and samples were subsequently prepared in reducing sample buffer containing SDS. All parameters, except DA, were measured by western blot. TH protein content was determined against a standard curve of known TH quantity from an in-house standard (calibrated PC12 cell extract) as previously described.' Soluble GFR- $a 1$ expression was also determined against a standard curve of known soluble GFR- $a 1$ quantity, and the GFR- $a 1$ standard was custom-ordered from R\&D Systems (recombinant rat GFR- $a 1$ ) with the amino acid sequence of rat GFR- $a 1$ from Asp25Leu445 with the addition of the following sequence of amino acids at the C-terminus: CSIEGR as previously described.' The soluble GFR- $\alpha 1$ standard curve ranged from 0.05 to $0.7 \mathrm{ng}, 10 \mu \mathrm{g}$ of protein from the VTA of a control 18 month old Brown-Norway/Fischer $344 \mathrm{~F}_{1}$ hybrid rat was loaded with the standards to serve as a protein carrier, and background GFR- $a 1$ immunoreactivity from this VTA sample was subtracted from the standard curve as previously described. Standard curves were used only for soluble GFR- $a 1$ and TH, and all nanograms of TH and nanograms of soluble GFR- $a 1$ values for both groups were within range of the standard curves. Following SDS gel electrophoresis on $10 \%$ gels, proteins were transferred onto nitrocellulose membranes for $500 \mathrm{~V}$ h in a $1 \times$ Tris/glycine/methanol buffer. The nitrocellulose membrane was stained with Ponceau $S$, and the amount of protein loaded was verified by the Ponceau S stain. Sample lanes stained with Ponceau S were scanned and quantified with ImageJ to normalize protein in each sample. This relative total served as an additional normalizing value to determine the quantity of each protein assayed. Results were expressed as either nanograms per total micrograms of protein loaded or immunoreactivity per total micrograms of protein loaded. Specific primary antibodies included: GLT-1 (Santa Cruz Biotechnologies, cat. no. 15317), GLAST (Novus Biologicals, cat. no. NB100-1869), EAAC1 (Alpha Diagnostic International, cat. no. EAAC11-A), TH (Millipore, cat. no. AB152), DA D 1 -receptor (Santa Cruz Biotechnologies, cat. no. sc-14001), DAT (Santa Cruz Biotechnologies, cat. no. sc-1433), and GFR- $a 1$ receptor (R\&D Systems, cat. no. AF560). Nominal protein loads for linear detection of each dependent measure were as follows: 5-10 $\mu \mathrm{g}$ (TH), 30-60 $\mu \mathrm{g}$ (insoluble and soluble GFR- $a 1$ receptor), 20-30 $\mu \mathrm{g}$ (GLT-1), 10-20 $\mu \mathrm{g}$ (GLAST), $60 \mu \mathrm{g}$ (EAAC1 and DA-D 1 receptor), and 10-60 $\mu \mathrm{g}$ (DAT). After primary treatment, blots were exposed to secondary antibody (swine anti-rabbit IgG or rabbit antigoat $\mathrm{IgG}$ ) for signal enhancement, followed by $1 \mathrm{~h}$ incubation with $\left[{ }^{125} \mathrm{I}\right]$ protein $\mathrm{A}$ (PerkinElmer, cat. no. NEX146). The blots were then exposed to Blue Ultra Autorad Film at 
$-80{ }^{\circ} \mathrm{C}$ to reveal immunoreactive areas on the blot, and immunoreactivity was determined by ImageJ analysis performed on scans of the film.

Although it is well-established that exercise increases neurotrophic factors such as GDNF, we could not determine whether our regimen affected GDNF expression due to limited tissue available, methodological considerations in tissue processing, and prioritizing to examining expression of its receptor.

\section{Statistics}

An unpaired two-tailed t-test was used to compare differences between exercise and nonexercise groups for DA tissue content and expression of TH protein, GFR- $\alpha 1$, DAT, DA-D 1 receptor, GLT-1, GLAST, and EAAC1. A paired two-tailed $t$ test was used to compare differences in striatal glutamate uptake between the two groups, given the method by which the assay was conducted. Composite scores were calculated to compare differences in total GFR- $a 1$ expression between the two groups and were derived by performing a transform analysis on insoluble GFR- $\alpha 1$ immunoreactivity per microgram of protein and nanograms of soluble GFR- $a 1$ per microgram of protein for all subjects. For this analysis, the $n$ value reported is based on the total number of observations derived from the transform analysis of insoluble and soluble GFR- $\alpha 1$ expression for each rat. A Pearson correlation was also performed for correlation analyses of total insoluble and soluble GFR- $\alpha 1$ expression and total nanograms of TH and DA recovered. We have previously shown that total nanograms of TH recovered was significantly correlated to total nanograms of DA recovered in the SN in aged rats. The Grubb's outlier test was conducted to determine any outliers within a given assay result in each group. Significance for all statistical tests was set at $p<0.05$.

\section{Supplementary Material}

Refer to Web version on PubMed Central for supplementary material.

\section{ACKNOWLEDGMENTS}

The authors wish to thank Victoria Fields and Brian Latimer for outstanding technical support.

Funding

This work was funded by the National Institute on Aging at the National Institutes of Health (R01AG040261 awarded to M.F.S.).

\section{ABBREVIATIONS}

$\begin{array}{ll}\text { PD } & \text { Parkinson's disease } \\ \text { DA } & \text { dopamine } \\ \text { TH } & \text { tyrosine hydroxylase } \\ \text { GDNF } & \text { glial cell line-derived neurotrophic factor } \\ \text { SN } & \text { substantia nigra }\end{array}$




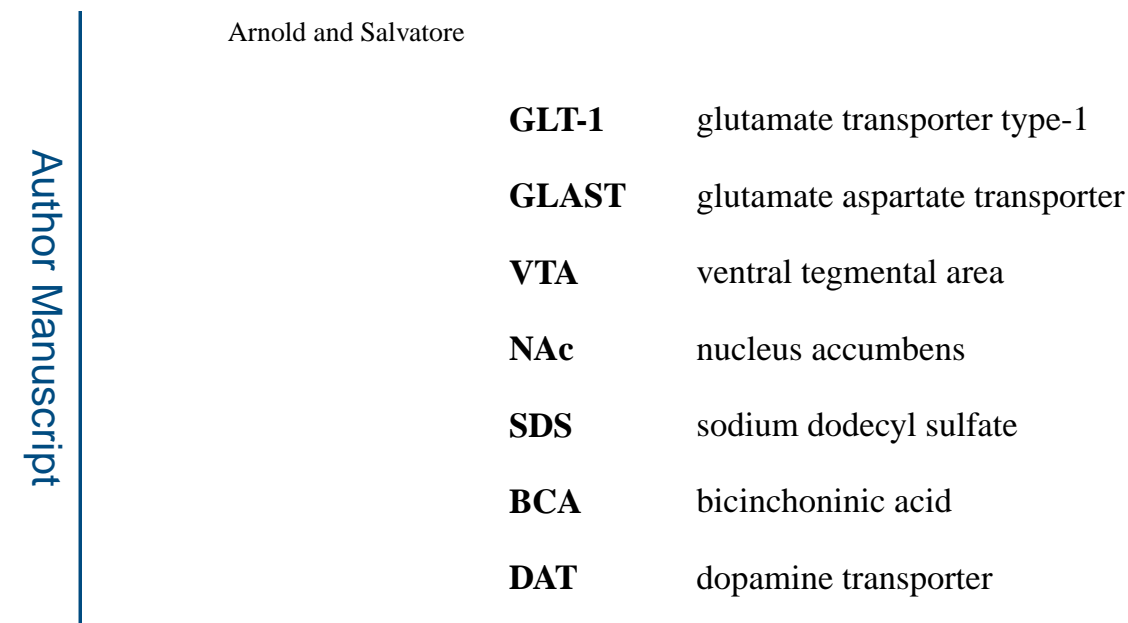

\section{REFERENCES}

1. Chen H, Zhang SM, Schwarzschild MA, Hernan MA, Ascherio A. Physical activity and the risk of Parkinson disease. Neurology. 2005; 64:664-669. [PubMed: 15728289]

2. Xu Q, Park Y, Huang X, Hollenbeck A, Blair A, Schatzkin A, Chen H. Physical activities and future risk of Parkinson's disease. Neurology. 2010; 75:341-348. [PubMed: 20660864]

3. Goodwin VA, Richards SH, Taylor RS, Taylor AH, Campbell JL. The effectiveness of exercise interventions for people with Parkinson's disease: a systematic review and meta-analysis. Mov. Disord. 2008; 23:631-640. [PubMed: 18181210]

4. Ridgel AL, Vitek JL, Alberts JL. Forced, not voluntary, exercise improves motor function in Parkinson's disease patients. Neurorehabil. Neural Repair. 2009; 23:600-608. [PubMed: 19131578]

5. Denison HJ, Syddall HE, Dodds R, Martin HJ, Finucane FM, Griffin SJ, Wareham NJ, Cooper C, Sayer AA. The effects of aerobic exercise on muscle strength and physical performance among community dwelling older people from the Hertfordshire Cohort Study: a randomized controlled trial. J. Am. Geriatr. Soc. 2013; 61:1034-1036. [PubMed: 23772733]

6. Ortman, JM.; Velkoff, VA.; Hogan, H. Current Population Reports P25-1140. U.S. Census Bureau, U.S. Government Printing Office; Washington, DC.: 2014. An Aging Nation: The Older Population in the United States.

7. Smith AD, Zigmond MJ. Can the brain be protected through exercise? Lessons from an animal model of parkinsonism. Exp. Neurol. 2003; 184:31-39. [PubMed: 14637076]

8. Tillerson JL, Caudle WM, Reveron ME, Miller GW. Exercise induces behavioral recovery and attenuates neuro-chemical deficits in rodent models of Parkinson's disease. Neuroscience. 2003; 119:899-911. [PubMed: 12809709]

9. Tajiri N, Yasuhara T, Shingo T, Kondo A, Yuan W, Kadota T, Wang F, Baba T, Tayra JT, Morimoto T, Jing M, Kikuchi Y, Kuramoto S, Agari T, Miyoshi Y, Fujino H, Obata F, Takeda I, Furuta T, Date I. Exercise exerts neuroprotective effects on Parkinson's disease model of rats. Brain Res. 2010; 1310:200-207. [PubMed: 19900418]

10. Lau YS, Patki G, Das-Panja K, Le WD, Ahmad SO. Neuroprotective effects and mechanisms of exercise in a chronic mouse model of Parkinson's disease of moderate neurodegeneration. Eur. J. Neurosci. 2011; 33:1264-1274. [PubMed: 21375602]

11. Bernheimer H, Birkmayer W, Hornykiewicz O, Jellinger K, Seitelberger F. Brain dopamine and the syndromes of Parkinson and Huntington. Clinical, morphological and neurochemical correlations. J. Neurol. Sci. 1973; 20:415-455. [PubMed: 4272516]

12. Hornykiewicz, O.; Kish, SJ. Biochemical pathophysiology of Parkinson's disease. In: Yahr, MD.; Bergmann, KJ., editors. Advances in Neurology. Vol. 45. Raven Press; New York: 1986. p. 19-34.

13. Bezard E, Dovero S, Prunier C, Ravenscroft P, Chalon S, Guilloteau D, Crossman AR, Bioulac B, Brotchie JM, Gross CE. Relationship between the appearance of symptoms and the level of nigrostriatal degeneration in a progressive 1-methyl-4-phenyl-1,2,3,6-tetrahydropyridine-lesioned Macaque model of Parkinson's disease. J. Neurosci. 2001; 21:6853-6861. [PubMed: 11517273] 
14. Irwin I, DeLanney LE, McNeill T, Chan P, Forno LS, Murphy GM, Di Monte DA, Sandy MS, Langston JW. Aging and the nigrostriatal dopamine system: a non-human primate study. Neurodegeneration. 1994; 3:251-265. [PubMed: 7531106]

15. Yurek M, Hipkens SB, Hebert MA, Gash DM, Gerhardt GA. Age-related decline in striatal dopamine release and motoric function in Brown Norway/Fischer 344 hybrid rats. Brain Res. 1998; 791:246-256. [PubMed: 9593919]

16. Gerhardt GA, Cass WA, Yi A, Zhang Z, Gash DM. Changes in somatodendritic but not terminal dopamine regulation in aged rhesus monkeys. J. Neurochem. 2002; 80:168-177. [PubMed: 11796755]

17. Cruz-Muros I, Afonso-Oramas D, Abreu P, Barroso-Chinea P, Rodríguez M, Gonzalez MC, Hernandez TG. Aging of the rat mesostriatal system: Differences between the nigrostriatal and the mesolimbic compartments. Exp. Neurol. 2007; 204:147-161. [PubMed: 17112516]

18. Salvatore MF, Pruett BS, Spann SL, Dempsey C. Aging reveals a role for nigral tyrosine hydroxylase ser31 phosphorylation in locomotor activity generation. PLoS One. 2009; 4:e8466. [PubMed: 20037632]

19. Salvatore MF, Pruett BS. Dichotomy of tyrosine hydroxylase and dopamine regulation between somatodendritic and terminal field areas of nigrostriatal and mesoaccumbens pathways. PLoS One. 2012; 7:e29867. [PubMed: 22242182]

20. Wolf ME, LeWitt PA, Bannon MJ, Dragovic LJ, Kapatos G. Effect of aging on tyrosine hydroxylase protein content and the relative number of dopamine nerve terminals in human caudate. J. Neurochem. 1991; 56:1191-1200. [PubMed: 1672141]

21. Kubis N, Faucheux BA, Ransmayr G, Damier P, Duyckaerts C, Henin D, Forette B, le Charpentier Y, Hauw JJ, Agid Y, Hirsch EC. Preservation of midbrain catecholaminergic neurons in very old human subjects. Brain. 2000; 123:366-373. [PubMed: 10648443]

22. Haycock JW, Becker L, Ang L, Furukawa Y, Hornykiewicz O, Kish SJ. Marked disparity between age related changes in dopamine and other presynaptic dopaminergic markers in human striatum. J. Neurochem. 2003; 87:574-585. [PubMed: 14535941]

23. McCormack AL, Di Monte DA, Delfani K, Irwin I, DeLanney LE, Langston WJ, Janson AM. Aging of the nigrostriatal system in the squirrel monkey. J. Comp. Neurol. 2004; 471:387-395. [PubMed: 15022260]

24. Emborg ME, Ma SY, Mufson EJ, Levey AI, Taylor MD, Brown WD, Holden JE, Kordower JH. Age-related declines in nigral neuronal function correlate with motor impairments in rhesus monkeys. J. Comp. Neurol. 1998; 401:253-265. [PubMed: 9822152]

25. Fisher BE, Petzinger GM, Nixon K, Hogg E, Bremmer S, Meshul CK, Jakowec MW. Exerciseinduced behavioral recovery and neuroplasticity in the 1-methyl-4-phenyl-1,2,3,6tetrahydropyridine-lesioned mouse basal ganglia. J. Neurosci. Res. 2004; 77:378-390. [PubMed: 15248294]

26. Petzinger GM, Walsh JP, Akopian G, Hogg E, Abernathy A, Arevalo P, Turnquist P, Vuckovic M, Fisher BE, Togasaki DM, Jakowec MW. Effects of treadmill exercise on dopaminergic transmission in the 1-methyl-4-phenyl-1,2,3,6-tetrahydropyridine-lesioned mouse model of basal ganglia injury. J. Neurosci. 2007; 27:5291-5300. [PubMed: 17507552]

27. O'Dell SJ, Gross NB, Fricks AN, Casiano BD, Nguyen TB, Marshall JF. Running wheel exercise enhances recovery from nigrostriatal dopamine injury without inducing neuroprotection. Neuroscience. 2007; 144:1141-1151. [PubMed: 17157992]

28. Park JS, Höke A. Treadmill exercise induced functional recovery after peripheral nerve repair is associated with increased levels of neurotrophic factors. PLoS One. 2014; 9:e90245. [PubMed: 24618564]

29. McCullough MJ, Gyorkos AM, Spitsbergen JM. Short-term exercise increases GDNF protein levels in the spinal cord of young and old rats. Neuroscience. 2013; 240:258-268. [PubMed: 23500094]

30. Hoffer BJ, Hoffman A, Bowenkamp K, Huettl P, Hudson J, Martin D, Lin LF, Gerhardt GA. Glial cell line-derived neurotrophic factor reverses toxin-induced injury to midbrain dopaminergic neurons in vivo. Neurosci. Lett. 1994; 182:107-111. [PubMed: 7891873] 
31. Gash DM, Zhang Z, Ovadia A, Cass WA, Yi A, Simmerman L, Russell D, Martin D, Lapchak PA, Collins F, Hoffer BJ, Gerhard GA. Functional recovery in parkinsonian monkeys treated with GDNF. Nature. 1996; 380:252-255. [PubMed: 8637574]

32. Grondin R, Cass WA, Zhang Z, Stanford JA, Gash DM, Gerhardt GA. Glial cell line-derived neurotrophic factor increases stimulus-evoked dopamine release and motor speed in aged rhesus monkeys. J. Neurosci. 2003; 23:1974-1980. [PubMed: 12629203]

33. Salvatore MF, Zhang JL, Large DM, Wilson PE, Gash CR, Thomas TC, Haycock JW, Bing G, Stanford JA, Gash DM, Gerhardt GA. Striatal GDNF administration increases tyrosine hydroxylase phosphorylation in the rat striatum and substantia nigra. J. Neurochem. 2004; 90:245254. [PubMed: 15198683]

34. Pruett BS, Salvatore MF. GFR-a1 receptor expression in the aging nigrostriatal and mesoaccumbens pathways. J. Neurochem. 2010; 115:707-715. [PubMed: 20731758]

35. Pruett BS, Salvatore MF. Nigral GFRa-1 infusion in aged rats increases locomotor activity, nigral tyrosine hydroxylase, and dopamine content in synchronicity. Mol. Neurobiol. 2013; 47:988-999. [PubMed: 23321789]

36. Farrand AQ, Gregory RA, Scofield MD, Helke KL, Boger HA. Effects of aging on glutamate neurotransmission in the substantia nigra of Gdnf heterozygous mice. Neurobiol. Aging. 2015; 36:1569-1576. [PubMed: 25577412]

37. Wang L, Deng QQ, Wu XH, Yu J, Yang XL, Zhong YM. Upregulation of glutamate-aspartate transporter by glial cell line-derived neurotrophic factor ameliorates cell apoptosis in neural retina in streptozotocin-induced diabetic rats. CNS Neurosci. Ther. 2013; 19:945-953. [PubMed: 23870489]

38. Arnold JC, Salvatore MF. Getting to compliance in forced exercise in rodents: a critical standard to evaluate exercise impact in aging-related disorders and disease. J. Visualized Exp. 2014; 90:e51827.

39. Matsuo A, Nakamura S, Akiguchi I. Immunohistochemical localization of glial cell line-derived neurotrophic factor family receptor alpha-1 in the rat brain: confirmation of expression in various neuronal systems. Brain Res. 2000; 859:57-71. [PubMed: 10720615]

40. Paratcha G, Ledda F, Baars L, Coulpier M, Besset V, Anders J, Scott R, Ibanez CF. Released GFRalpha1 potentiates downstream signaling, neuronal survival, and differentiation via a novel mechanism of recruitment of c-Ret to lipid rafts. Neuron. 2001; 29:171-184. [PubMed: 11182089]

41. Salvatore MF. Ser31 tyrosine hydroxylase phosphor-ylation parallels differences in dopamine recovery in nigrostriatal pathway following 6-OHDA lesion. J. Neurochem. 2014; 129:548-558. [PubMed: 24410633]

42. Salvatore MF, Gerhardt GA, Dayton RD, Klein RL, Stanford JA. Bilateral effects of unilateral GDNF administration on dopamine- and GABA-regulating proteins in the nigrostriatal system. Exp. Neurol. 2009; 219:197-207. [PubMed: 19460370]

43. Wichmann T, Kleim MA. Neuronal activity in the primate substantia nigar pars reticulate during the performance of simple and memory-guided elbow movements. J. Neurophysiol. 2003; 91:815827. [PubMed: 14762150]

44. Kliem MA, Maidment NT, Ackerson LC, Chen S, Smith Y, Wichmann T. Activation of nigral and pallidal dopamine D1-like receptors modulates basal ganglia outflow in monkeys. J. Neurophysiol. 2007; 98:1489-1500. [PubMed: 17634344]

45. Trevitt JT, Carlson BB, Nowend K, Salamone JD. Substantia nigra pars reticulate is a highly potent site of action for the behavioral effects of the D1 antagonist SCH23390 in rat. Psychopharmacol. 2001; 156:32-41.

46. Chen Y, Swanson RA. The glutamate transporters EAAT2 and EAAT3 mediate cysteine uptake in cortical neuron cultures. J. Neurochem. 2003; 84:1332-1339. [PubMed: 12614333]

47. Aoyama K, Suh SW, Hamby AM, Hamby AM, Liu J, Chan WY, Chen Y, Swanson RA. Neuronal glutathione deficiency and age-dependent neurodegeneration in the EAAC1 deficient mouse. Nat. Neurosci. 2006; 9:119-126. [PubMed: 16311588]

48. Aoyama K, Nakaki T. Glutathione in cellular redox homeostasis: association with the excitatory amino acid carrier (EAAC1). Molecules. 2015; 20:8742-8758. [PubMed: 26007177] 
49. Konishi Y, Yang LB, He P, Lindholm K, Lu B, Li R, Shen Y. Deficiency of GDNF receptor GFRa1 in Alzheimer's neurons results in neuronal death. J. Neurosci. 2014; 34:13127-13138. [PubMed: 25253858]

50. Maheu M, Lopez JP, Crapper L, Davoli MA, Turecki G, Mechawar N. MicroRNA regulation of central glial cell line-derived neurotrophic factor GDNF signaling in depression. Transl. Psychiatry. 2015; 5:e511. [PubMed: 25689572]

51. Gomez-Pinilla F, Hillman C. The influence of exercise on cognitive abilities. Compr. Physiol. 2013; 3:403-428. [PubMed: 23720292]

52. Tuon T, Valvassori SS, Dal Pont GC, Paganini CS, Pozzi BG, Luciano TF, Souza PS, Quevedo J, Souza CT, Pinho RA. Physical training prevents depressive symptoms and a decrease in brainderived neurotrophic factor in Parkinson's disease. Brain Res. Bull. 2014; 108:106-112. [PubMed: 25264157]

53. Gerecke KM, Jiao Y, Pani A, Pagala V, Smeyne RJ. Exercise protects against MPTP-induced neurotoxicity in mice. Brain Res. 2010; 1341:72-83. [PubMed: 20116369]

54. Mijatovic J, Airavaara M, Planken A, Auvinen P, Raasmaja A, Piepponen P, Costantini F, Ahtee L, Saarma M. Constitutive Ret activity in knock-in multiple endocrine neoplasia type B mice induces profound elevation of brain dopamine concentration via enhanced synthesis and increases the number of TH-positive cells in the substantia nigra. J. Neurosci. 2007; 27:4799-4809. [PubMed: 17475787]

55. Zigmond MJ, Smeyne RJ. Exercise: is it neuroprotective and if so, how does it work? Parkinsonism Relat. Disord. 2014; 20:S123-S127. [PubMed: 24262162]

56. Robinson MB, Dowd LA. Heterogeneity and functional properties of subtypes of sodiumdependent glutamate transporters in the mammalian central nervous system. Adv. Pharmacol. 1996; 37:69-115. [PubMed: 8891100]

57. Shashidharan P, Huntley GW, Murray JM, Buku A, Moran T, Walsh MJ, Morrison JH, Plaitakis A. Immunohistochemical localization of the neuron-specific glutamate transporter EAAC1 (EAAT3) in rat brain and spinal cord revealed by a novel monoclonal antibody. Brain Res. 1997; 773:139148. [PubMed: 9409715]

58. Zerangue N, Kavanaugh MP. Interaction of L-cysteine with a human excitatory amino acid transporter. J. Physiol. 1996; 493:419-423. [PubMed: 8782106]

59. Berman AE, Chan WY, Brennan AM, et al. NAcetylcysteine prevents loss of dopaminergic neurons in the EAAC1 ${ }^{-/}$mouse. Ann. Neurol. 2011; 69:509-520. [PubMed: 21446024]

60. Smeyne M, Smeyne RJ. Glutathione metabolism and Parkinson's disease. Free Radical Biol. Med. 2013; 62:13-25. [PubMed: 23665395]

61. Nickell J, Salvatore MF, Pomerleau F, Apparsundaram S, Gerhardt GA. Reduced plasma membrane surface expression of GLAST mediates decreased glutamate regulation in the aged striatum. Neurobiol. Aging. 2007; 28:1737-1748. [PubMed: 16959378]

62. Chotibut T, Davis RW, Arnold JC, Frenchek Z, Gurwara S, Bondada V, Geddes JW, Salvatore MF. Ceftriaxone increases glutamate uptake and reduces striatal tyrosine hydroxylase in 6-OHDA Parkinson's model. Mol. Neurobiol. 2014; 49:1282-1292. [PubMed: 24297323]

63. Rothstein JD, Martin L, Levey AI, Dykes-Hoberg M, Jin L, Wu D, Nash N, Kuncl RW. Localization of neuronal and glial glutamate transporters. Neuron. 1994; 13:713-725. [PubMed: 7917301]

64. Kim K, Lee SG, Kegelman TP, Su ZZ, Das SK, Dash R, Dasgupta S, Barral PM, Hedvat M, Diaz P, Reed JC, Stebbins JL, Pellecchia M, Sarkar D, Fisher PB. Role of excitatory amino acid transporter-2 (EAAT2) and glutamate in neurodegeneration: opportunities for developing novel therapeutics. J. Cell. Physiol. 2011; 226:2484-2493. [PubMed: 21792905]

65. Salvatore MF, Davis RW, Arnold JC, Chotibut T. Transient striatal GLT-1 blockade increases EAAC1 expression, glutamate reuptake, and decreases tyrosine hydroxylase phosphorylation at ser19. Exp. Neurol. 2012; 234:428-436. [PubMed: 22285253]

66. Neeper SA, Gomez-Pinilla F, Choi J, Cotman CW. Physical activity increases mRNA for brainderived neurotrophic factor and nerve growth factor in rat brain. Brain Res. 1996; 726:49-56. [PubMed: 8836544] 
67. Berchtold NC, Chinn G, Chou M, Kesslak JP, Cotman CW. Exercise primes a molecular memory for brain-derived neurotrophic factor protein induction in the rat hippocampus. Neuroscience. 2005; 133:853-861. [PubMed: 15896913]

68. Gerecke KM, Jiao Y, Pagala V, Smeyne RJ. Exercise does not protect against MPTP-induced neurotoxicity in BDNF haploinsufficient mice. PLoS One. 2012; 7:e43250. [PubMed: 22912838]

69. Salvatore MF, Pruett BS, Dempsey C, Fields V. Comprehensive profiling of dopamine regulation in substantia nigra and ventral tegmental area. J. Visualized Exp. 2012; 66:4171.

70. Henn FA, Anderson DJ, Rustad DG. Glial contamination of synaptosomal fractions. Brain Res. 1976; 101:341-344. [PubMed: 1244976]

71. Suchak SK, Baloyianni NV, Perkinton MS, Williams RJ, Meldrum BS, Rattray M. The 'glial' glutamate transporter, EAAT2 (Glt-1) accounts for high affinity glutamate uptake into adult rodent nerve endings. J. Neurochem. 2003; 84:522-532. [PubMed: 12558972]

72. Nickell J, Pomerleau F, Allen J, Gerhardt GA. Age-related changes in the dynamics of potassiumevoked L-glutamate release in the striatum of Fisher 344 rats. J. Neural Transm. 2005; 112:87-96. [PubMed: 15599607]

73. Wassum KM, Tolosa VM, Wang J, Walker E, Monbouquette HG, Maidment NT. Silicon waferbased platinum microelectrode array biosensor for near real-time measurement of glutamate in vivo. Sensors. 2008; 8:5023-5036. [PubMed: 19543440] 


\begin{tabular}{|c|c|c|}
\hline Week 1 & Weeks 2-3 & Weeks 4-8 \\
\hline Pre-Exercise Phase & Treadmill Acclimation Phase & Treadmill Exercise Phase \\
\hline $\begin{array}{l}\text { Baseline Locomotor } \\
\text { Activity: } \\
60 \text { min/day; } 5 \text { days } \\
\text { Assign exercise \& non- } \\
\text { exercise groups using } \\
5 \text { locomotor measures: } \\
\text { 1) Total distance } \\
\text { 2) Horizontal activity } \\
\text { 3) Movement Number } \\
\text { 4) Movement time } \\
\text { 5) Movement Speed }\end{array}$ & $\begin{array}{l}\text { Stage } 1 \text { of Acclimation: } \\
\text { All subjects sit on stationary } \\
\text { treadmill; } 5-10 \mathrm{~min} / \text { day, } 3 \text { days } \\
\text { Day } 1: 5 \mathrm{~min} \\
\text { Day } 2: 7 \mathrm{~min} \\
\text { Day } 3: 10 \mathrm{~min} \\
\text { Stage } 2 \text { of Acclimation: } \\
\text { All subjects undergo acclimation } \\
\text { training, } 5-10 \mathrm{~min} / \text { day, } 7 \text { days } \\
\text { Days } 1-3: 5-7 \mathrm{~m} / \mathrm{min}, 5-10 \mathrm{~min} \\
\text { Days } 4-7: 8-10 \mathrm{~m} / \mathrm{min}, 8-10 \mathrm{~min}\end{array}$ & $\begin{array}{l}\text { Treadmill Exercise Training: } \\
1 \text { round of exercise }=12 \text { days } \\
\text { Rest period: } 14 \text { days } \\
\text { Exercise group: } \\
\text { Warm up: } 8 \mathrm{~m} / \mathrm{min}, 5 \mathrm{~min} \\
\text { Remainder of training session: } 9-11 \\
\mathrm{~m} / \mathrm{min}, 30 \mathrm{~min} \\
\text { Non-Exercise Group: } \\
\text { Sit on stationary treadmill for } 35 \mathrm{~min} \text { for } \\
\text { each exercise session }\end{array}$ \\
\hline \multicolumn{3}{|c|}{$\begin{array}{c}\text { Body weight measurements assessed immediately before (first session) and after (last session) } \\
\text { each phase of the treadmill exercise regimen }\end{array}$} \\
\hline
\end{tabular}

Figure 1.

Treadmill exercise regimen timeline. Treadmill exercise regimen was composed of three phases: the pre-exercise, treadmill acclimation, and treadmill exercise phases. During the pre-exercise phase (week 1), baseline locomotor activity was determined for each test subject to assess locomotor capabilities prior to treadmill exercise. Exercise and nonexercise groups were assigned such that there was an equal representation of locomotor activity in both groups. Treadmill acclimation (weeks 2-3) was completed in two stages. In stage 1 , all subjects sat on the stationary treadmill for 5-10 min per day for 3 days to acclimate to the treadmill environment. All exercise and non-exercise rats were then trained to walk on the treadmill at low to moderate speeds for 5-10 min per day for 7 days during the second stage of treadmill acclimation. During the treadmill exercise phase (weeks 4-8), exercise rats underwent two round of exercise, where each round consisted of 12 days of exercise. A 2 week rest period separated the two rounds of exercise. During this phase, exercise rats exercised for $35 \mathrm{~min}$ per day, whereas the non-exercise cohorts sat on the stationary treadmill for 35 min per day. Body weight was measured before (first session) and after (last session) each phase of this regimen as previously reported. 


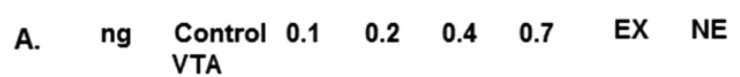

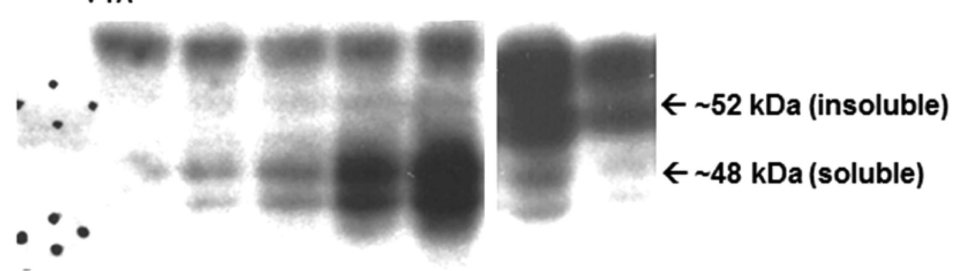

B. $\mathrm{SN}$

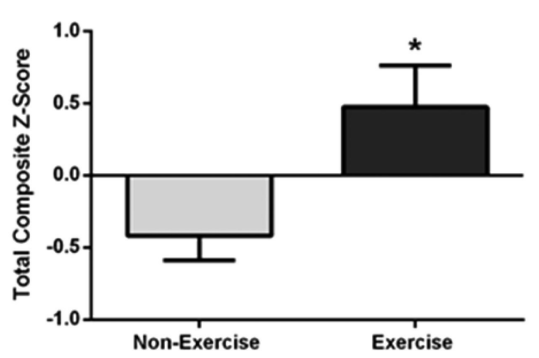

E. Striatum

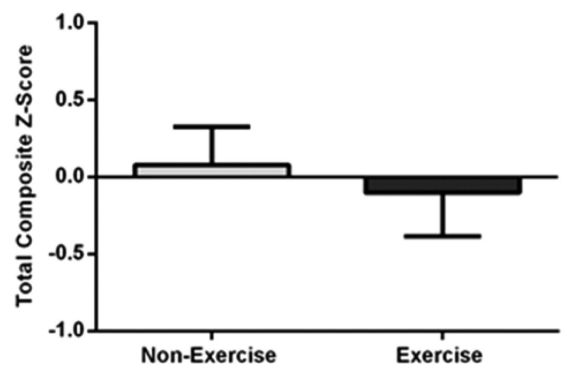

\section{C. $\mathrm{SN}$}

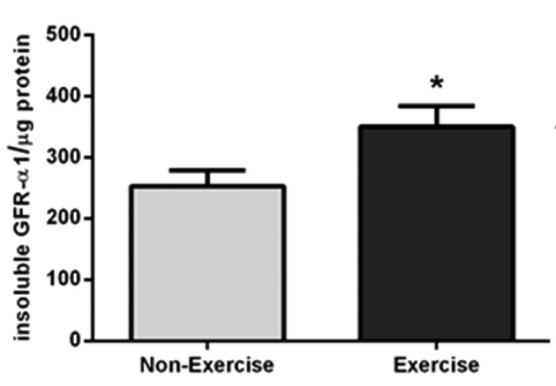

F. Striatum

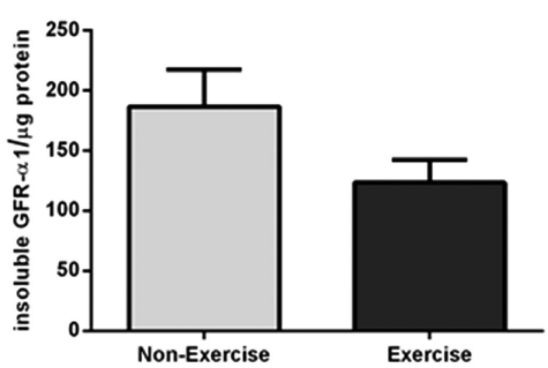

D. $\mathrm{SN}$

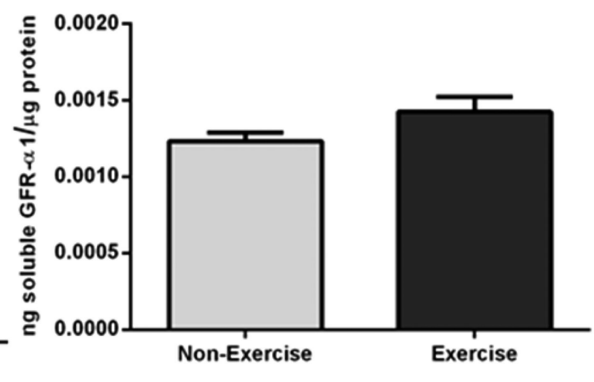

G. Striatum

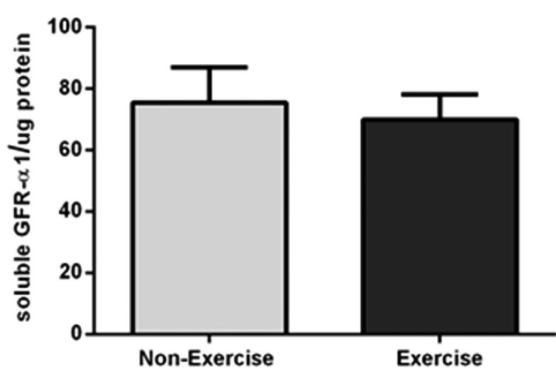

Figure 2.

Effects of exercise on GFR- $\alpha 1$ expression in the nigrostriatal pathway. Results are expressed as total composite $z$-score (total GFR- $a 1$ ), insoluble GFR- $a 1$ per microgram of protein (insoluble GFR- $a 1$ ), or nanograms of soluble GFR- $a 1$ per microgram of protein (soluble GFR- $a 1$ ). For soluble GFR- $a 1$ in striatum, results are expressed as soluble GFR- $a 1$ per microgram of protein due to low immunoreactivity of the soluble GFR- $a 1$ standard curve. A two-tailed unpaired $t$-test was used to compare differences in total, insoluble, and soluble GFR- $a 1$ expression in exercise versus non-exercise cohorts. Data are presented as mean \pm SEM. (A) Representative western blot of immunoreactivity against GFR- $a 1$. Representative western blot showing a soluble GFR- $a 1$ standard curve and the effect of exercise upon GFR$a 1$ immunoreactivity in the SN of one exercise and non-exercise rat. The soluble GFR- $a 1$ standard curve ranged from 0.1 to $0.7 \mathrm{ng}$, and $10 \mu \mathrm{g}$ of protein from VTA of an 18 month old control Brown-Norway/Fischer $344 \mathrm{~F}_{1}$ hybrid rat was loaded with the standards to serve as a protein carrier. Background GFR- $a 1$ immunoreactivity from this VTA sample was subtracted from the standard curve as described previously. Two immunoreactive bands were detected in all four brain regions: the insoluble GFR- $a 1$ band $(\sim 52 \mathrm{kDa})$ and the soluble GFR- $a 1$ band ( 48 kDa). (B) Total GFR- $a 1$ in SN. Total GFR- $a 1$ expression was significantly increased in the SN following exercise ( $n=16$ (non-exercise), $n=14$ (exercise), $t=2.745, * p<0.05)$. (C) Insoluble GFR- $a 1$ in SN. Insoluble GFR- $a 1$ expression was significantly increased in the exercise cohort compared to that in the non-exercise 
cohort ( $n=8$ per group, $t=2.318,{ }^{*} p<0.05$ ). (D) Soluble GFR- $\alpha 1$ in SN. There was a trend toward significantly increased soluble GFR- $\alpha 1$ expression in exercise rats after exercise compared to that in non-exercise rats $(n=8$ per group, $t=1.741, p=0.10)$. (E) Total GFR$a 1$ in striatum. Total GFR- $a 1$ expression was not significantly different following exercise ( $n=16$ (non-exercise), $n=13$ (exercise), $t=0.489, p=0.63$ ). (F) Insoluble GFR- $\alpha 1$ in striatum. Insoluble GFR- $\alpha 1$ expression was not significantly different between the groups after exercise ( $n=8$ (non-exercise), $n=6$ (exercise), $t=1.599, p=0.14$ ). (G) Soluble GFR$a 1$ in striatum. There was no significant difference in soluble GFR- $\alpha 1$ expression following exercise ( $n=8$ per group, $t=0.389, p=0.70)$. 

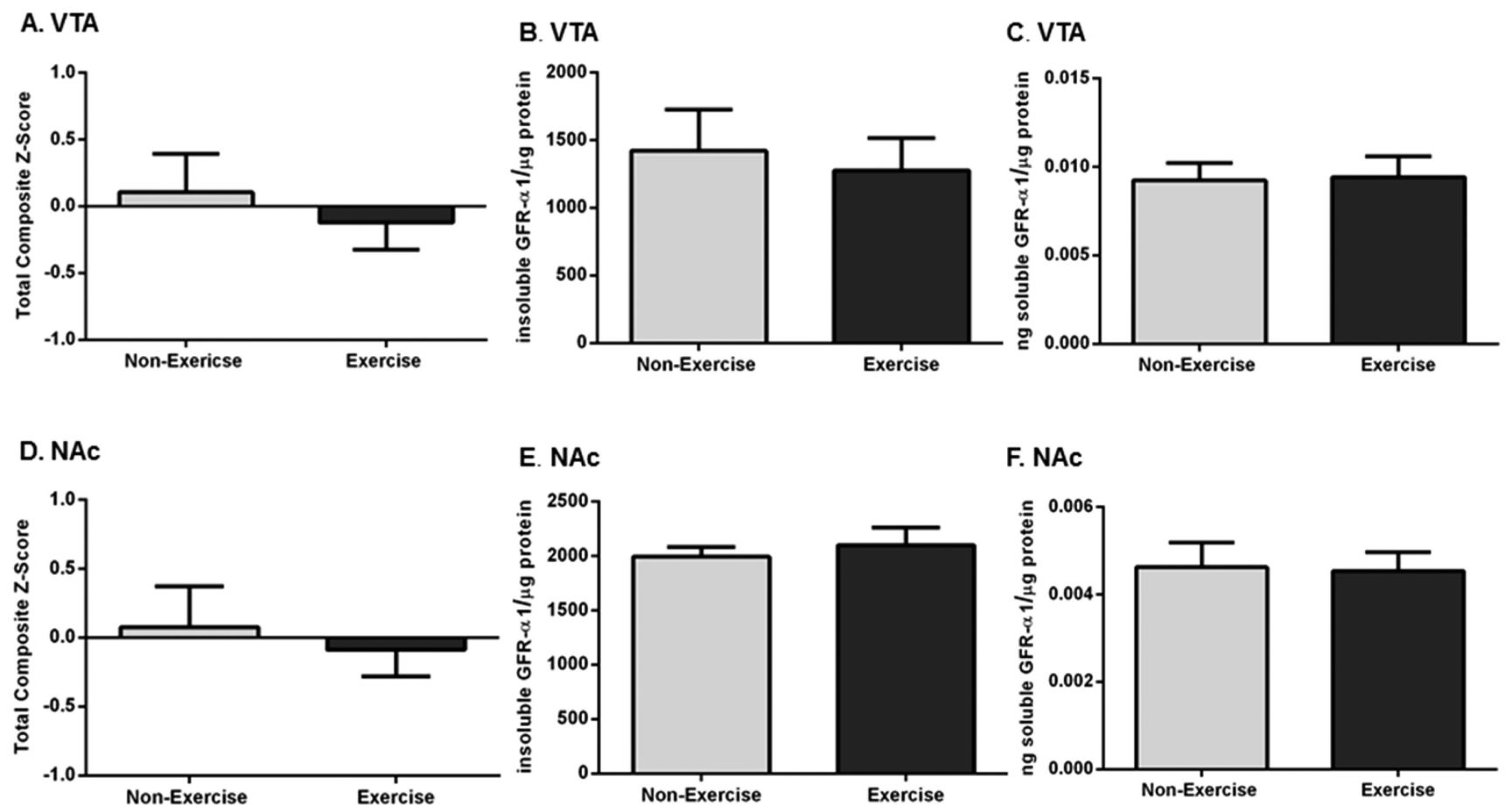

F. NAc

Figure 3.

Effects of exercise on GFR- $a 1$ expression in the mesoaccumbens pathway. Results are expressed as total composite score (total GFR- $a 1$ ), insoluble GFR- $a 1$ per microgram of protein (insoluble GFR- $a 1$ ), or nanograms of soluble GFR- $a 1$ per microgram of protein (soluble GFR- $a 1$ ). A two-tailed unpaired $t$-test was used to compare differences in total, insoluble, and soluble GFR- $\alpha 1$ expression in exercise versus non-exercise cohorts. Data are presented as mean \pm SEM. (A) Total GFR- $a 1$ in the VTA. Total GFR- $a 1$ expression was not significantly different in the VTA after exercise ( $n=16$ (non-exercise), $n=14$ (exercise), $t=$ $0.622, p=0.54)$. (B) Insoluble GFR- $a 1$ in the VTA. Insoluble GFR- $a 1$ expression was not significantly different between the two groups after exercise ( $n=8$ per group, $t=0.373, p=$ 0.71). (C) Soluble GFR- $a 1$ in the VTA. There was no significant difference in soluble GFR$a 1$ expression following exercise ( $n=8$ per group, $t=0.117, p=0.91$ ). (D) Total GFR- $a 1$ in the NAc. Total GFR- $a 1$ expression was not significantly different between the groups after exercise ( $n=14$ per group, $t=0.453, p=0.65$ ). (E) Insoluble GFR- $a 1$ in the NAc. Insoluble GFR- $a 1$ expression was not significantly different in the exercise cohort after exercise compared to that in the non-exercise cohort ( $n=8$ per group, $t=0.580, p=0.57)$. $(\mathrm{F})$ Soluble GFR- $a 1$ in the NAc. There was no significant difference in soluble GFR- $a 1$ expression between the groups ( $n=8$ per group, $t=0.116, p=0.91$ ). 


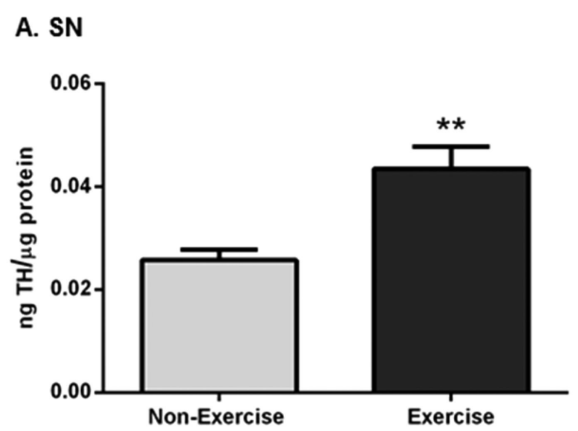

\author{
B. Striatum
}

C. VTA
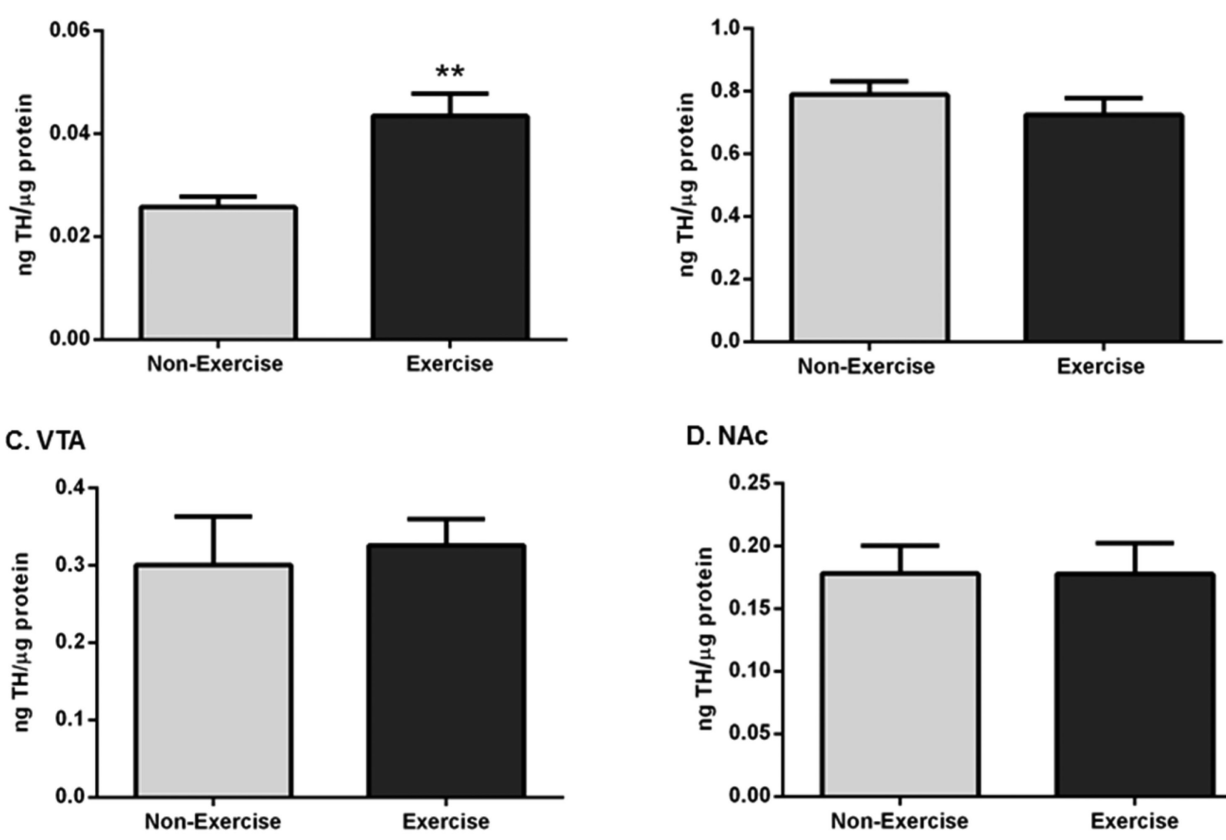

D. NAC

$\begin{array}{llllllll}\text { E. } & \text { ng } & 0.5 & 1.0 & 1.5 & 2.0 & 4.0 & \text { EX NE }\end{array}$

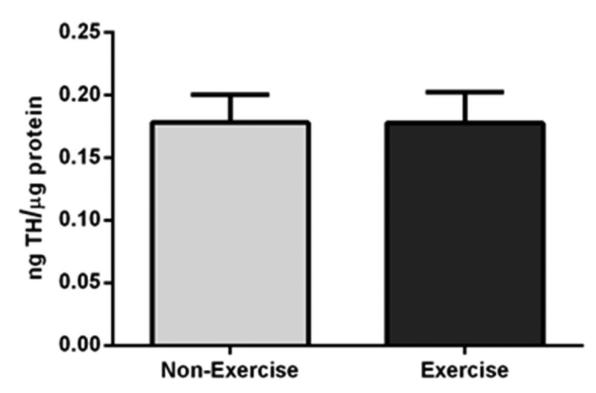

Figure 4.

TH protein expression in the nigrostriatal and mesoaccumbens pathways following exercise. Results are expressed as nanograms of TH per microgram of protein and were analyzed by a two-tailed unpaired $t$-test to compare differences in TH protein expression between the two groups after exercise. Data are presented as mean \pm SEM. (A) SN. There was a significant increase in TH protein expression following exercise ( $n=8$ (non-exercise), $n=7$ (exercise), $t=3.851, * * p<0.01)$. (B) Striatum. TH protein expression was not significantly different after exercise ( $n=7$ (non-exercise), $n=8$ (exercise), $t=0.926, p=0.37$ ). (C) VTA. There was no significant difference in TH protein expression after exercise ( $n=8$ per group, $t=$ $0.353, p=0.73$ ). (D) NAc. TH protein expression was not significantly different between the groups following exercise ( $n=8$ per group, $t=0.016, p=0.99$ ). (E) Representative western blot of immunoreactivity against $\mathrm{TH}$. A representative western blot depicting a $\mathrm{TH}$ standard curve and the effect of exercise upon $\mathrm{TH}$ immunoreactivity in the $\mathrm{SN}$ of one exercise and one non-exercise rat. A TH standard curve, ranging from 0.5 to $4.0 \mathrm{ng}$, was run in combination with all samples from the four brain regions. 


\section{A. $\mathrm{SN}$}

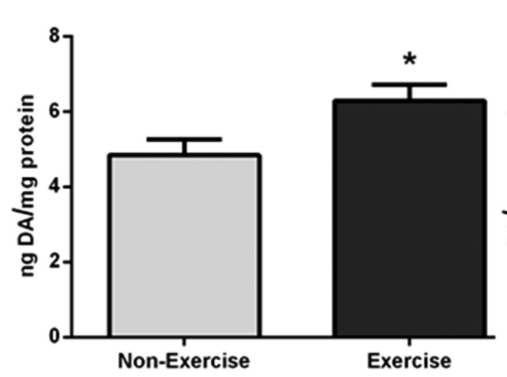

B. VTA

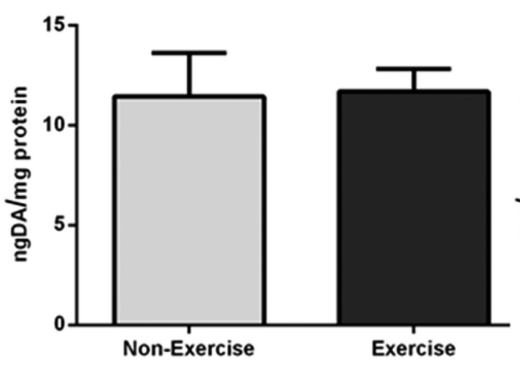

C. NAC

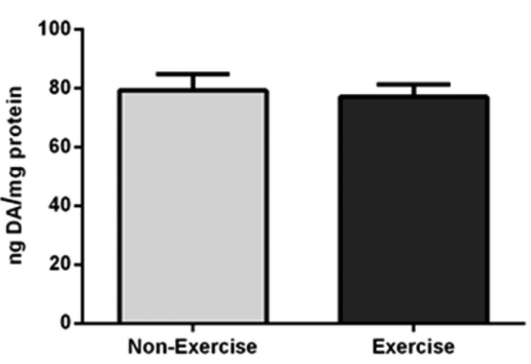

Figure 5.

DA tissue content in the SN, VTA, and NAc following exercise. Results are expressed as nanograms of DA per milligram of protein and were analyzed by a two-tailed unpaired $t$-test to compare differences in DA tissue content between the exercise group after exercise and the non-exercise group. Data are presented as mean \pm SEM. (A) SN. DA tissue content was significantly increased in exercise rats compared to that in non-exercise rats $(n=8$ (nonexercise), $n=7$ (exercise), $t=2.465,{ }^{*} p<0.05$ ). (B) VTA. DA tissue content was not significantly different between the two groups after exercise $(n=8$ per group, $t=0.107, p=$ 0.92). (C) NAc. DA tissue content was not significantly different following exercise $(n=8$ per group, $t=0.303, p=0.77$ ). 

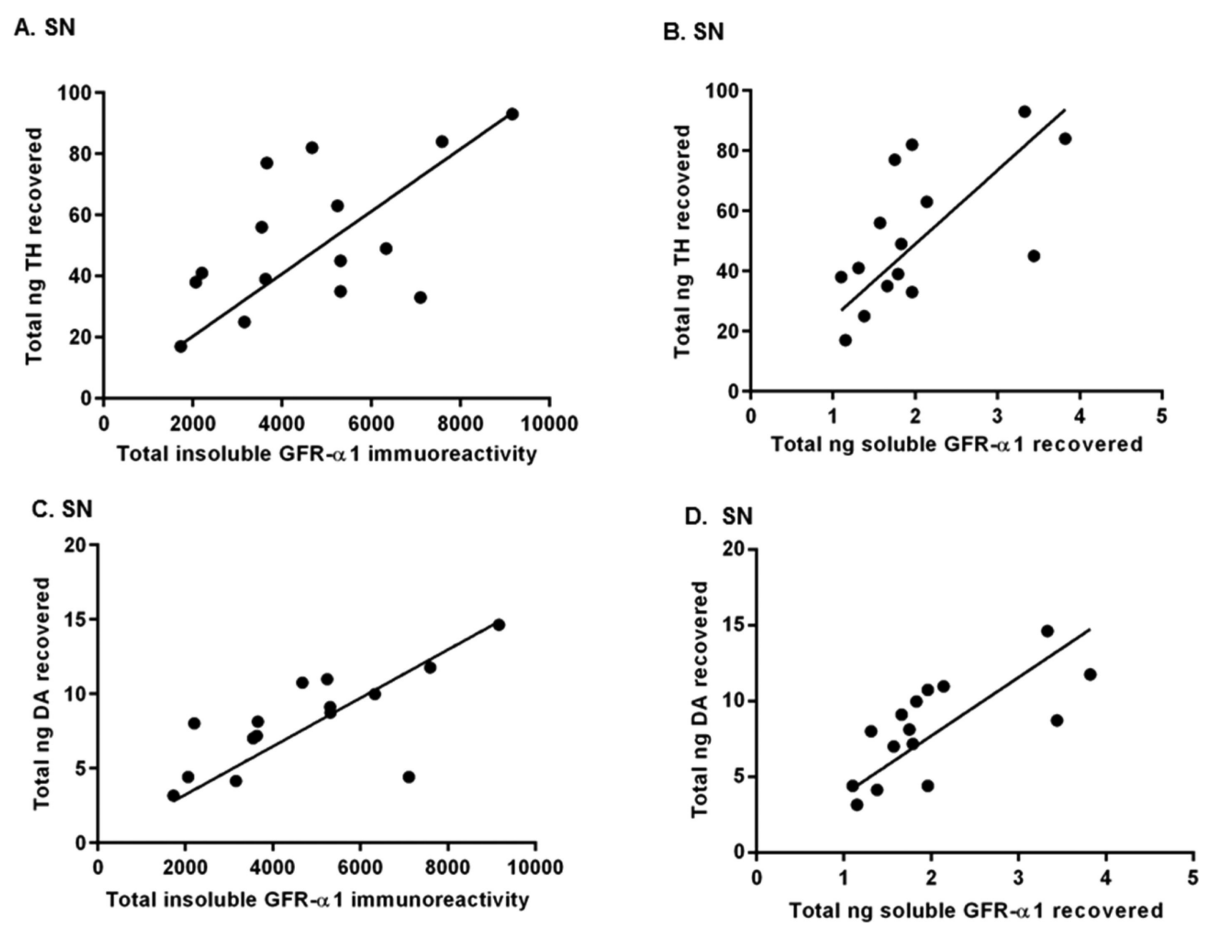

Figure 6.

Relationship of GFR- $\alpha 1$ expression to TH protein and DA tissue content in the SN following exercise. A Pearson correlational analysis determined if there were relationships of total insoluble GFR- $\alpha 1$ immunoreactivity (insoluble GFR- $\alpha 1$ immunoreactivity per microgram of protein assayed for each sample multiplied by total micrograms protein recovered in the sample) or total nanograms of soluble GFR- $\alpha 1$ recovered (nanograms of soluble GFR- $\alpha 1$ per microgram of protein assayed for each sample multiplied by total micrograms of protein recovered in the sample) to both total nanograms of TH recovered (nanograms of TH per microgram of protein assayed for each sample multiplied by total micrograms of protein recovered in the sample) and nanograms of DA recovered (nanograms of DA per microgram of protein assayed for each sample multiplied by total micrograms of protein recovered in the sample) in the SN ( $n=8$ (non-exercise), $n=7$ (exercise)). (A) Correlation of insoluble GFR- $a 1$ and TH in SN. There was a significant correlation between total insoluble GFR- $a 1$ immunoreactivity and total nanograms of TH recovered $\left(n=15\right.$, Pearson $r=0.58,{ }^{*} p<$ 0.05). (B) Correlation of soluble GFR- $a 1$ and TH in SN. Total nanograms of soluble GFR$a 1$ recovered and total nanograms of TH recovered were significantly correlated ( $n=15$, Pearson $r=0.63, * p<0.05$ ). (C) Correlation of insoluble GFR- $a 1$ and DA in SN. There was a significant correlation between total insoluble GFR- $\alpha 1$ immunoreactivity and total nanograms of DA recovered ( $n=15$, Pearson $r=0.71,{ }^{* *} p<0.01$ ). (D) Correlation of soluble GFR- $a 1$ and DA in SN. There was a significant correlation between total nanograms of soluble GFR- $a 1$ recovered and total nanograms of DA recovered $(n=15$, Pearson $r=$ $0.70, * * p<0.01)$. 
A. $\mathrm{SN}$

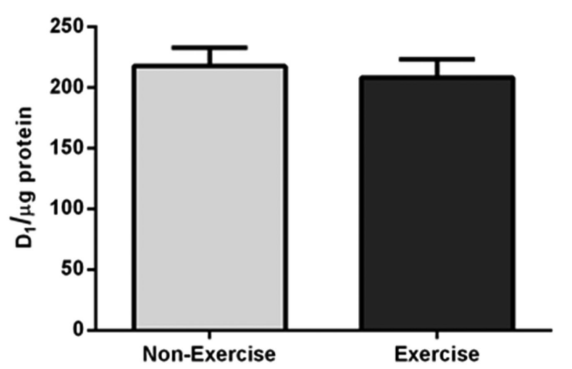

C. VTA

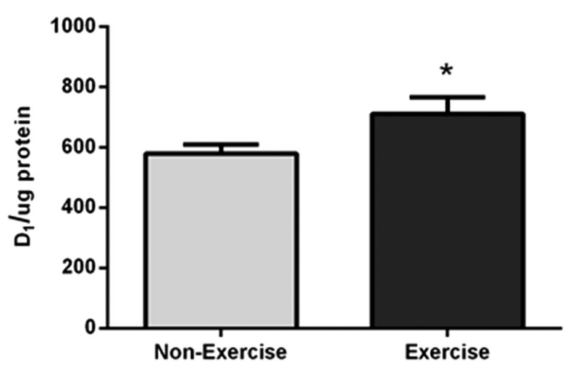

E. NE EX

\section{B. Striatum}

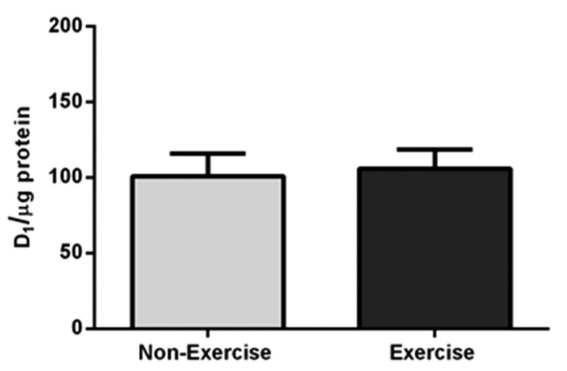

D. NAc

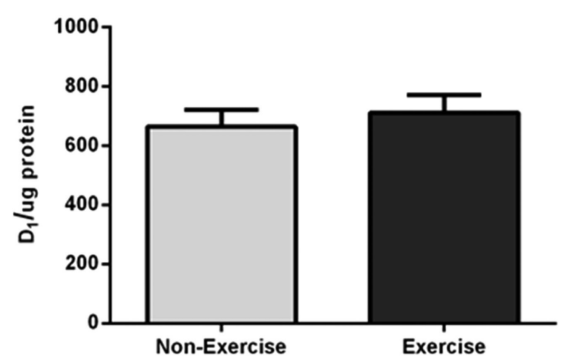

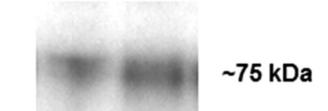

Figure 7.

DA-D $D_{1}$ receptor expression in the nigrostriatal and mesoaccumbens pathways following exercise. Results are expressed as $\mathrm{D}_{1}$ per microgram of protein, and a two-tailed unpaired $t$ test was used to determine relative differences in $\mathrm{DA}^{-\mathrm{D}_{1}}$ receptor expression between the two groups. Data are presented as mean \pm SEM. (A) $S N$. $D_{1}$ receptor protein expression was not significantly different in exercise rats compared to that in non-exercise rats $(n=8$ per group, $t=0.440, p=0.67$ ). (B) Striatum. $\mathrm{D}_{1}$ receptor expression was not significantly different following exercise ( $n=8$ (non-exercise), $n=7$ (exercise), $t=0.255, p=0.80$ ). (C) VTA. $D_{1}$ receptor expression was significantly increased following exercise $(n=8$ per group, $t=2.152$, $* p<0.05$ ). (D) NAc. $\mathrm{D}_{1}$ receptor protein expression was not significantly different between the groups ( $n=8$ per group, $t=0.517, p=0.58$ ). (E) Representative western blot of $\mathrm{DA}-\mathrm{D}_{1}$ receptor immunoreactivity. A representative blot showing the effect of exercise upon $\mathrm{D}_{1}$ receptor immunoreactivity in the VTA of one exercise and one nonexercise rat. 


\section{A. $\mathrm{SN}$}

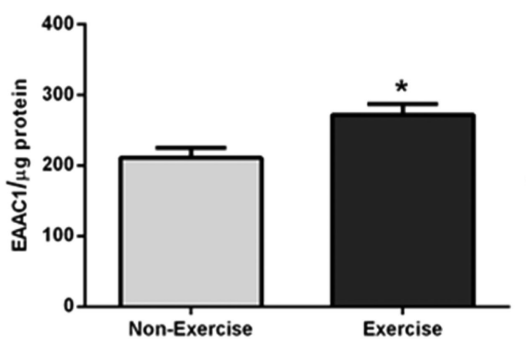

D. Striatum

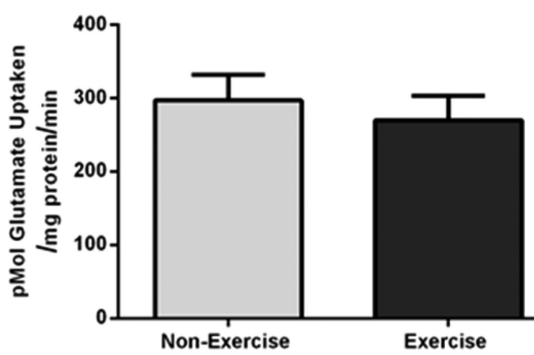

G.

$$
\text { B. SN }
$$

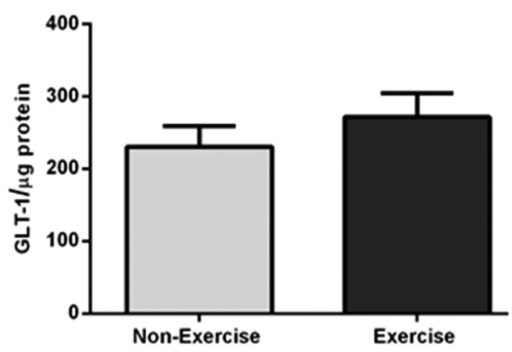

E. Striatum

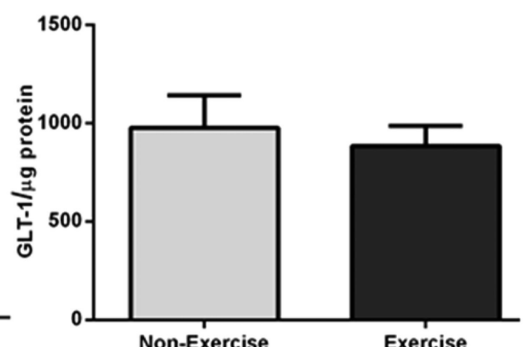

C. SN

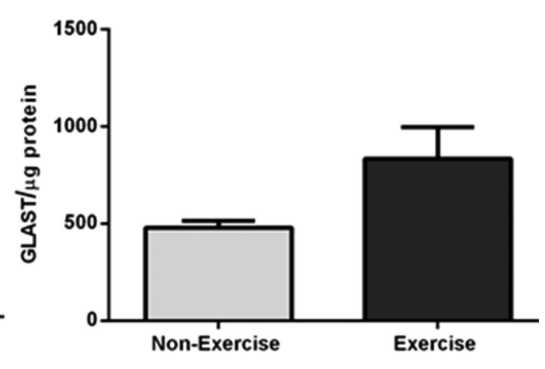

F. Striatum

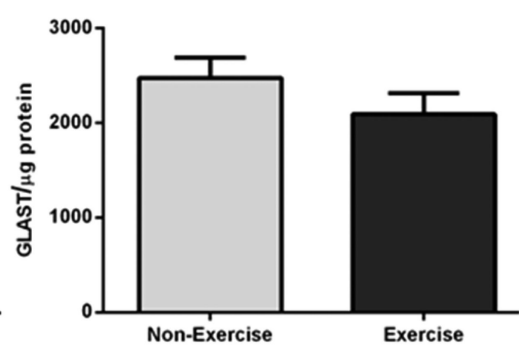

EX EX NE NE

$\sim 69 \mathrm{kDa}$

Figure 8.

Nigrostriatal glutamate transporter expression and striatal glutamate uptake following exercise. Results are expressed as EAAC1 per microgram of protein, GLT-1 per microgram of protein, GLAST per microgram of protein, or picomoles of glutamate uptaken per milligram of protein per minute, and a two-tailed paired $t$-test was used to determine relative differences in striatal glutamate uptake, whereas an unpaired two-tailed $t$-test was used to determine differences in glutamate transporter expression between the two groups. Data are presented as mean \pm SEM. (A) EAAC1 in SN. There was a significant increase in EAAC1 expression after exercise ( $n=8$ (non-exercise), $n=7$ (exercise), $t=2.933, * p<0.05$ ). (B) GLT-1 in SN. There was no significant difference in GLT-1 expression between the groups after exercise ( $n=8$ per group, $t=0.942, p=0.36$ ). (C) GLAST in SN. There was a trend toward a significant increase in GLAST expression in exercise rats compared to that in nonexercise rats ( $n=8$ per group, $t=2.142, p=0.050$ ). (D) Glutamate uptake in striatum. There was no significant difference in glutamate uptake between the groups after exercise ( $n=6$ per group, $t=0.731, p=0.50$ ). (E) GLT-1 in striatum. There was no significant difference in GLT-1 expression after exercise ( $n=8$ per group, $t=0.475, p=0.64$ ). (F) GLAST in striatum. There was no significant difference in GLAST expression between the two groups ( $n=8$ per group, $t=1.247, p=0.23$ ). (G) Representative western blot for immunoreactivity against EAAC1. A representative blot showing the effect of exercise upon EAAC1 immunoreactivity in the $\mathrm{SN}$ of one exercise and one non-exercise rat. 


\section{Table 1}

Summary of the Neurochemical Parameters Assayed in the Nigrostriatal and Mesoaccumbens Pathways Following Two Rounds of Exercise in Aging Rats ${ }^{a}$

\begin{tabular}{|c|c|c|c|c|c|c|c|}
\hline brain region & neurochemical parameter & $\begin{array}{l}\text { change } \\
\text { compared to } \\
\text { non-exercise } \\
\text { group }\end{array}$ & $p$-value & brain region & neurochemical parameter & $\begin{array}{l}\text { change } \\
\text { compared to } \\
\text { non-exercise } \\
\text { group }\end{array}$ & $p$-value \\
\hline \multirow[t]{11}{*}{$\mathrm{SN}$} & total GFR- $a 1$ & $\uparrow$ & ${ }^{*} p<0.05$ & striatum & total GFR- $a 1$ & - & $p=0.63$ \\
\hline & insoluble GFR- $a 1$ & $\uparrow$ & ${ }^{*} p<0.05$ & & insoluble GFR- $a 1$ & - & $p=0.14$ \\
\hline & soluble GFR- $a 1$ & - & $p=0.10$ & & soluble GFR- $a 1$ & - & $p=0.70$ \\
\hline & $\mathrm{TH}$ & $\uparrow$ & $\stackrel{* *}{p}<0.01$ & & $\mathrm{TH}$ & - & $p=0.37$ \\
\hline & DA tissue content & $\uparrow$ & ${ }^{*} p<0.05$ & & DA tissue content & not measured & NA \\
\hline & DAT & not measured & NA & & DAT & - & $p=0.21$ \\
\hline & $\mathrm{D}_{1}$ receptor & - & $p=0.67$ & & $\mathrm{D}_{1}$ receptor & - & $p=0.80$ \\
\hline & EAAC1 & $\uparrow$ & ${ }^{*} p<0.05$ & & EAAC1 & not measured & NA \\
\hline & GLT-1 & - & $p=0.36$ & & GLT-1 & - & $p=0.64$ \\
\hline & GLAST & $\uparrow$ & $p=0.05$ & & GLAST & - & $p=0.23$ \\
\hline & glutamate uptake & not measured & NA & & glutamate uptake & - & $p=0.50$ \\
\hline \multirow[t]{7}{*}{ VTA } & total GFR- $a 1$ & - & $p=0.54$ & NAc & total GFR- $a 1$ & - & $p=0.65$ \\
\hline & insoluble GFR- $a 1$ & - & $p=0.71$ & & insoluble GFR- $a 1$ & - & $p=0.57$ \\
\hline & soluble GFR- $a 1$ & - & $p=0.91$ & & soluble GFR- $a 1$ & - & $p=0.91$ \\
\hline & $\mathrm{TH}$ & - & $p=0.73$ & & $\mathrm{TH}$ & - & $p=0.99$ \\
\hline & DA tissue content & - & $p=0.92$ & & DA tissue content & - & $p=0.77$ \\
\hline & DAT & - & $p=0.72$ & & DAT & - & $p=0.58$ \\
\hline & $\mathrm{D}_{1}$ receptor & $\uparrow$ & ${ }^{*} p<0.05$ & & $\mathrm{D}_{1}$ receptor & - & $p=0.58$ \\
\hline
\end{tabular}

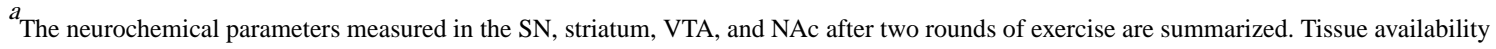
prevented analysis of some neurochemical parameters within specific brain regions, which is denoted "not measured" in the table. When significant differences between exercise and non-exercise groups were observed following exercise, the direction of the change, with respect to the nonexercise group, is indicated as $\uparrow$ (significant increase), whereas - (no change) indicates no significant difference between the two groups. An unpaired $t$-test was used to determine significant differences for all parameters assayed with the exception of striatal glutamate uptake. A paired $t$ test was used to determine if differences in glutamate uptake occurred between the exercise and non-exercise groups, given the method by which the assay was conducted. The two-tailed $p$-values are listed for each parameter for all four brain regions, and significance is indicated as follows:

*

$p<0.05$

** $p<0.01$
} 